\title{
PRODUÇÃO DE CONHECIMENTO DOS TRABALHOS DE CONCLUSÃO DE CURSO DOS CURSOS DE TURISMO DE GOIÂNIA
}

Nilda Maria de Freitas

Orientadora: Prof. MsC Maria Regina Zamith Calazans

Monografia apresentada ao Centro de Excelência em Turismo da Universidade de Brasília como requisito parcial para a obtenção do Certificado de Especialista em Docência e Pesquisa em Turismo e Hospitalidade 


\begin{abstract}
UNIVERSIDADE DE BRASÍLIA
Centro de Excelência em Turismo

Curso de Especialização em Pesquisa e Docência em Turismo e Hospitalidade
\end{abstract}

\title{
PRODUÇÃO DE CONHECIMENTO DOS TRABALHOS DE CONCLUSÃO DE CURSO DOS CURSOS DE TURISMO DE GOIÂNIA
}

Nilda Maria de Freitas

Banca Examinadora

Prof. Ms Maria Regina Zamith Calazans

Orientadora

Prof. Dra. Tânia Siqueira Montoro

Prof. Dra. Tereza Negrão

Brasília, DF, 04 de Dezembro de 2003

Folha de Aprovação 
Freitas, Nilda Maria.

Produção de Conhecimento dos Trabalhos de Conclusão de Curso dos Cursos de Turismo de Goiânia. Goiânia - GO, 2003, 62p.

Monografia de Especialização em Pesquisa e Docência em Turismo e Hospitalidade.

1. Produção de conhecimento

2. Pesquisa

3. Turismo 
Nilda Maria de Freitas

\title{
PRODUÇÃO DE CONHECIMENTO DOS TRABALHOS DE CONCLUSÃO DE CURSO DOS CURSOS DE TURISMO DE GOIÂNIA
}

\author{
Comissão Examinadora \\ Prof. MsC Maria Regina Zamith Calazans \\ Orientadora
}

Prof. Dra. Tânia Siqueira Montoro

Prof. Dra. Tereza Negrão

Brasília, DF, 04 de Dezembro de 2003 


\section{Dedicatória}

Aos meus filhos Isabella, João Henrique e Tamires, que compreenderam e me apoiaram na minha ausência para realização do curso, e a meu marido Antônio Henrique amigo e companheiro em todos os momentos de nossa jornada. 


\section{AGRADECIMENTOS}

A Deus por sua infinita bondade e proteção, dando-me forças para concluir mais essa jornada.

A Gracinha e Durval que nos receberam com tanto carinho em sua casa, apoiando e incentivando durante esse percurso.

A Graça e Pedro que com gentileza e atenção facilitaram nossos momentos no Cet.

Aos mestres que contribuíram para nosso aprendizado, partilhando seus conhecimentos, vivências e atenção.

As professoras, Tânia e Tereza, pela paciência de ouvir nossas reclamações, inseguranças, insatisfações e saber, acima de tudo, compreendê-las.

Á professora Regina que com sua meiguice, carinho, atenção, conhecimento e sempre pronta a ouvir e nos dar força para continuarmos.

Ao professor, José Luiz Braga, que mesmo não fazendo parte do corpo docente do Cet, soube com sua sabedoria e conhecimento nos ouvir e orientar.

Á turma maravilhosa com a qual convivemos por 13 meses. 
O prazer de aprender

Sublima-se na arte de ensinar.

\section{Nilda Freitas}

Envelhece-se rápido na Universidade Pode-se deitar espírito refinado, e Encher-se de espanto por se acordar obtuso.

\section{Francisque Sarcey}




\section{RESUMO}

Os trabalhos de final de curso nos cursos de graduação no que se refere a pesquisa, na maioria das vezes, são tão sintetizados, resumidos e pouco aprofundadas, que os alunos acabam por não conhecer" a real importância da pesquisa na produção de conhecimento, para sua vida profissional, da atenção que deve ser dedicada à elaboração de projetos de pesquisa e das orientações fundamentais de que necessitam para avançar no processo por meio das disciplinas que se destinam a esse fim.

O objetivo deste trabalho foi de verificar a produção de conhecimento dos trabalhos de final de curso dos cursos de turismo de Goiânia. Foram analisados 18 trabalhos apresentados pelos graduados no período de junho de 2002 a junho de 2003, das duas IES que formaram turma nesse período.

A análise dos trabalhos teve por critério verificar a relevância dos temas, conteúdo, pesquisa, respeitando a iniciação do acadêmico na produção do conhecimento e a contribuição desses trabalhos para o saber turístico.

Palavras-chave: turismo - pesquisa - conhecimento 
RESUMEN

Los trabajos de final de curso en los cursos de graduación en lo que refiere a la investigación, en la mayoria de las veces son tan sintetizados, resumidos y poco profundizados que los alumnos acaban no conociendo la real importancia de la investigación en la producción de conocimiento para su vida profesional, de la atención que debe ser dedicada a la elaboración de proyetos de investigación y de las orientaciones fundamentales que necesitan para avanzar en el proceso por medio de las asignaturas que se destinan a ese fin.

El objetivo de este trabajo fue verificar la producción de conocimiento de los trabajos de final de curso de los cursos de Turismo de Goiania. Fueron analizados 18 trabajos presentados por los graduandos en el período de junio de 2002 hasta junio de 2003, de las dos Instituciones de Enseñanza Superior (IES) que graduaron grupo en este período.

El análisis de los trabajos tuvo como criterio verificar la relevancia de los temas, contenido, investigación, respetando la iniciación del alumno en la producción del conocimiento y la contribución de esos trabajos para el saber turístico.

Palabras clave: turismo - investigación - conocimiento 


\section{SUMÁRIO}

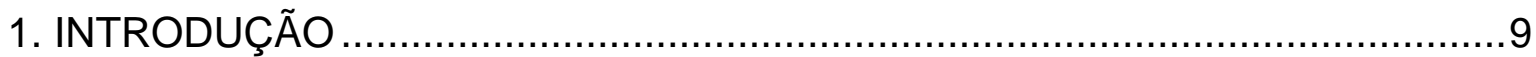

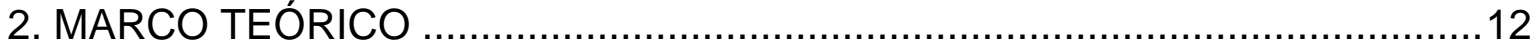

2.1. A epistemologia no turismo ..................................................... 13

2.1.1. Epistemologia do turismo no Brasil ............................................... 17

2.2. Educação, Ciência e Sociedade .................................................. 21

2.3. Ensino Superior, pesquisa científica e interdisciplinaridade. ....................23

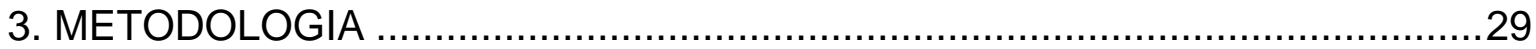

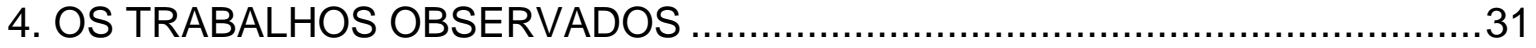

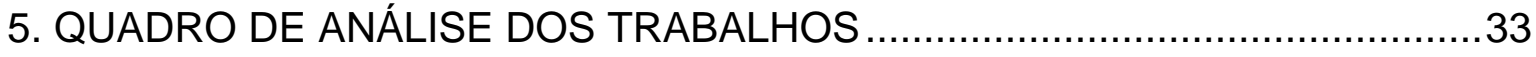

6. ANÁLISE DOS TRABALHOS QUANTO À PRODUÇÃO DO CONHECIMENTO

6.1. Tema: Intervalo Literário - uma alternativa de marketing cultural para o turismo goianiense 41

6.2. Tema: Inclusão social na Hotelaria: CIT-TUR. .......................................45

6.3. Tema: A Dinâmica das Visitas Técnicas das IES de Goiânia...................47

7. CONSIDERAÇÕES FINAIS ............................................................ 49

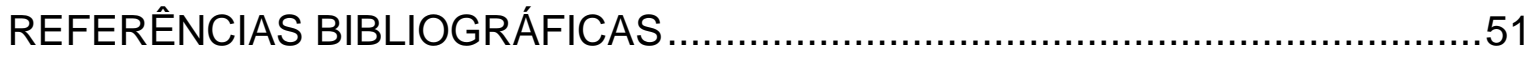

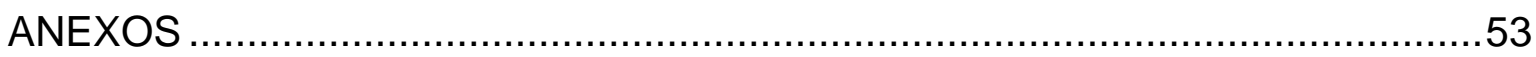

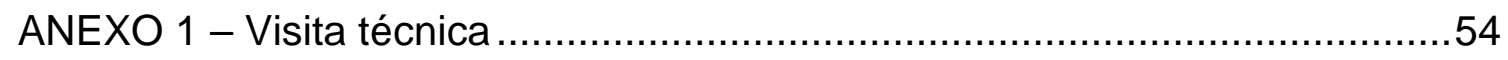

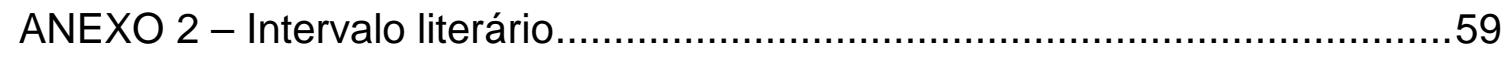

ANEXO 3 - Inclusão social na hotelaria - CIT-TUR ...............................60 


\section{INTRODUÇÃO}

O ensino superior, na amplitude de atribuição do termo, tem como proposta a formação dos estudantes nos mais diversos aspectos. Ensinar-lhes conceitos e relações novas; levá-los a compreender "idéias", propondo diferentes informações a suas memórias; exercitá-los na utilização de métodos e de técnicas (comportamentais ou intelectuais) fundamentais. Objetivos que correspondem, de modo geral, à "instrução". Entendendo, porém, que o ensino completo não se reduz à instrução, é preciso complementar com um conjunto de ações voltadas à formação e ao desenvolvimento conjugado da personalidade do estudante ao qual o ensino é dirigido. Na conjugação dessas dimensões tem-se a educação.

Além disso, a educação do ensino superior confronta-se com algumas exigências de nossa sociedade industrial que são muito difíceis de harmonizar, como a da quantidade e a da qualidade, a das necessidades técnicas e a de uma cultura geral.

De tempos em tempos, um curso de ensino superior é considerado o curso do "momento" ou o curso da "moda", todo mundo quer fazer. Com o turismo não foi diferente. O primeiro curso no Brasil surgiu na década de 1970 na AnhembiMorumbi, São Paulo. De acordo com Ansarah, no ano de 1994, existiam 29 cursos de turismo e, em 1998, já havia 157 cursos e no ano de 1999 foram autorizados 37 novos cursos. Em 2000, o número cresceu expressivamente, sendo 69 novos cursos autorizados pelo MEC. E um número surpreendente foi divulgado na Folha de São Paulo em 27 de Maio de 2001: o curso de turismo no Brasil cresceu 900\% em dez anos, em 250 instituições e 94\% dessas eram particulares.

No Brasil, entretanto, o ensino superior na área de turismo apresenta ainda tênue preocupação para com a pesquisa na graduação. Nos cursos existentes, conforme pesquisa da Professora Miriam Rejowski ${ }^{1}$, detectaram-se apenas dois centros de pesquisa recém-ativados. No entanto, tais dados devem

\footnotetext{
${ }^{1}$ REJOWSKI, Mirian. Turismo e pesquisa científica. 5ed.. Campinas, SP: Papirus, 1996. (Coleção Turismo)
} 
ser ponderados, considerando que os cursos inseridos em universidades devem enfatizar a pesquisa científica. Disto depreende-se que:

a) o desenvolvimento das pesquisas nos cursos de graduação em turismo das universidades é realizado, na maioria das vezes, sem um setor específico de apoio à mesma;

b) os cursos de graduação em turismo de institutos isolados ou inseridos em federações de escolas buscam uma formação técnico-profissional, em que a pesquisa não é privilegiada;

c) com as "universidades emergentes", tende-se a valorizar a pesquisa na formação de estudantes de graduação em turismo.

Com base nessas reflexões, uma série de questionamentos chamou-me a atenção desde 1998, quando começou o primeiro curso de turismo em Goiânia, no qual ingressei. Em 2003 já se somavam 8 cursos de turismo e um de administração em turismo e, em junho/2002, duas instituições formaram sua primeira turma, num total aproximado de 70 alunos. E, em 2003, já eram 4 instituições formando turmas, somando um total de formandos no período de junho/2002 a dezembro/2003, de aproximadamente 500 bacharéis em turismo e administradores em turismo. Se há 500 bacharéis formados, obviamente, têm-se 500 trabalhos de final de curso concluídos.

No entanto, as instituições diferem nas exigências quanto aos trabalhos de conclusão de curso: duas IES solicitam trabalhos e/ou projetos voltados para o mercado turístico, podendo ser onde realizou-se o estágio ou não, e ainda limitam os segmentos, pois o curso oferece opção de ênfase; uma IES não vincula o estágio ao TCC, podendo ser qualquer tipo de pesquisa e em qualquer segmento do turismo. A outra, o TCC é o relatório de estágio supervisionado.

É neste contexto que se questiona o papel das IES (Instituição de Ensino Superior), do professor-orientador e do orientando, e os trabalhos de conclusão de curso como produção de conhecimento apreendido no decorrer do curso.

A quase inexistente produção do conhecimento oriundo de trabalhos da graduação esbarra na complexidade do processo de ensino que depende, ao mesmo tempo, dos que aprendem e dos que ensinam. Assim, antes de denunciar a incapacidade da maioria dos estudantes, deve-se perguntar se existe, por parte das IES e dos professores, empenho em despertar o interesse dos alunos em estimulá-los ao esforço e à autovalorização; se existe nas IES incentivos à 
pesquisa, ou seja, iniciação científica, núcleos de pesquisa, laboratórios adequados e bibliotecas que atendam as necessidades para realização de pesquisas.

Os objetos de estudo para realização da pesquisa foram algumas monografias do curso de turismo de duas IES de Goiânia, que formaram turmas no período de junho de 2002 a junho de 2003. Para melhor compreensão dos trabalhos, fez-se um "Quadro de Análises dos Trabalhos", onde se contemplou: tema, problema, hipóteses, objetivos e metodologia. A partir desse quadro, escolheu-se três trabalhos para uma análise reflexiva, procedendo a uma leitura de compreensão e identificando a coerência do tema, com objetivos, justificativa e conteúdo, e a proposta interdisciplinar dos mesmos, pois uma característica intrínseca do curso de turismo é justamente a interdisciplinaridade.

As considerações finais sintetizam os resultados da análise dos trabalhos escolhidos; refletem sobre sua possível contribuição para a produção do conhecimento ou da construção da massa crítica do turismo; e fazem uma breve discussão da atual situação na produção de conhecimento nos cursos de graduação em turismo no Brasil. 
"fertilização" de um domínio por outro...A compartimentação da ciência a que assistimos hoje Uma das fontes do progresso científico é a torna esta "fertilização" mútua cada vez mais rara e difícil.

M. Magat

\section{MARCO TEÓRICO}

Das idéias de Platão, aos princípios de Aristóteles, do cogito de Descartes, das categorias a priori de Kant, que são questões da aceitação de alguns princípios fundadores que permeiam a própria construção do conhecimento, o constructo da ciência ou da produção do conhecimento, perpassa por um processo de condições, altercações, reflexões e aceitação de alguns saberes, permeados pelo método, isto é, o meio de se comprovar a cientificidade do que é proposto.

E conforme Dencker (2000, p.68)

Nenhuma pesquisa se inicia do nada. Toda investigação é parte de um processo cumulativo de aquisição de conhecimento e se enquadra em um modelo teórico a partir do qual se fazem deduções. Esse modelo serve para guiar o pesquisador na formulação do problema e na indicação das hipóteses que serão estudadas. (...)

É na seção "Marcos teóricos" do projeto que se analisa a situação atual do conhecimento mediante a revisão da literatura existente, buscandose pesquisas similares sobre o tema, conceitos, explicações e modelos teóricos existentes com o objetivo de situar o estudo no contexto geral do conhecimento.

O marco teórico foi desenvolvido a partir de pesquisas bibliográficas e documentais, que respondem aos questionamentos, objetivos e hipóteses relacionados no projeto, amparando-se em estudos realizados por alguns autores consagrados e outros nem tanto como:

-Ada de Freitas Maneti Dencker com os livros: Métodos e Técnicas de Pesquisa em Turismo e Pesquisa e Interdisciplinaridade no Ensino Superior;

-Jucinara Vargas Carvalho com o ensaio: O desenvolvimento da autonomia/autoria na construção da produção escrita e da pesquisa;

-Marutschka Moesch com o livro: A produção do saber turístico;

-Mirian Rejowski com o livro produzido a partir de sua tese de doutorado: Turismo e Pesquisa Científica;

-Alexandre Shigunov Neto e Lizete S.B. Maciel com o livro: Currículo e formação profissional, organizado com textos de vários autores; 
-Luiz Gonzaga Godoi Trigo e Alexandre Panosso Netto com o livro: Reflexões sobre um novo turismo: política, ciência e sociedade;

-Marília Gomes dos Reis Ansarah com o livro: Formação e Capacitação do Profissional em turismo e Hotelaria.

Cabe ainda destacar que foi realizada uma leitura criteriosa dos trabalhos citados, e a partir daí construiu-se o marco teórico, numa coletânea de autores e interferências pessoais e entendendo que em alguns momentos, a transcrição na íntegra fez-se necessário pela relevância do texto e melhor compreensão do mesmo.

\subsection{A epistemologia no turismo}

O turismo apesar de ser considerado um fenômeno envolvendo aspectos econômicos, sociais, culturais, psicológicos, ressente-se de uma epistemologia que estabeleça uma teoria que explique suas bases e articule suas (multi) facetas.

O descaso dos filósofos para com o turismo esbarra no "preconceito" de vulgarização da ciência filosófica, reduzindo-a a uma pseudofilosofia com a insignificância da reflexão do saber turístico.

Apesar de tanto descaso por parte dos filósofos, há vários estudiosos pesquisando e desenvolvendo trabalhos científicos, servindo de base para os primeiros passos no avanço da construção do conhecimento do turismo.

Entender o que é epistemologia, é imprescindível na discussão do saber turístico.

Segundo Trigo (2003, p.58), pode-se entender a epistemologia como a teoria do conhecimento, e surgiu como um modo de tratar um problema nascido de um pressuposto filosófico específico, no âmbito de determinada corrente filosófica, que é o idealismo. Ela estuda a realidade das coisas, ou seja, o mundo externo ao ser humano.

Partindo dos pressupostos que o conhecimento é uma categoria do espírito (intelecto) e que o objeto imediato do conhecimento é a idéia ou a representação, 
que está na consciência do sujeito pensante, conclui-se que a epistemologia busca verificar o que é válido no conhecimento de determinado fenômeno. É importante ressaltar ainda que, essa "realidade das coisas" se refere ao sentido filosófico, que busca o fim último das questões da natureza (sua razão de ser e sua essência) e não somente os aspectos superficiais (seus acidentes e externalidades).

Por ser um modo de verificar os fundamentos conceituais, ou seja, a validade do que se conhece em uma determinada área, a epistemologia aplica-se a todas as disciplinas acadêmicas que se conhecem. Em cada disciplina existe um método específico, ou vários, para tal verificação. Por isso, existe uma epistemologia do Direito, uma epistemologia da Filosofia, uma epistemologia da Psicologia, e assim por diante. Entretanto, não se pode ainda dizer que existe uma epistemologia do Turismo, pois a mesma ainda está em fase de elaboração.

Segundo Centeno (2003, p.2-3),

o primeiro passo para obter conhecimento sobre o turismo é observar e examinar o fenômeno para descrevê-lo e, nessa descrição, captar suas características essenciais e gerais. (...) Para conhecer, requer-se a consciência ou sujeito e todos os fatos relacionados com turismo que constituem o objeto de estudo.

A função do sujeito consiste em apreender o objeto, e a deste, em ser apreendido e assimilado pela consciência. Conhece-se, quando se consegue deslocar as propriedades do objeto em direção à consciência e essa imagem, enquanto finaliza as características do objeto de estudo, é objetiva. Ter-se-á um conhecimento verdadeiro do turismo se houver concordância entre o conteúdo do pensamento e o objeto de estudo, quer dizer, concordância entre a imagem formada na consciência e o objeto verdadeiro.

Partindo do pressuposto de que não existe uma epistemologia do turismo, argumenta-se que sua "criação" (melhor seria dizer seu estabelecimento ou seu uso), é imprescindível. Quando se fala que é importante uma epistemologia do turismo, quer dizer que é necessário aplicar esse modo de interpretação (validação/teste) no (do) conhecimento construído que se tem do turismo.

A epistemologia aplicada ao estudo do turismo, segundo Tribe (1997, p. 639 apud Trigo, 2003, p. 59), tem importância fundamental. Primeiro, porque ela promove uma revisão sistemática do que é legítimo no conhecimento do turismo e 
segundo, porque não há concordância sobre o mapa ou os limites dos estudos turísticos, e, nesse sentido, a epistemologia pode ajudar para que tais limites sejam estabelecidos.

Jovicic (1988, p.2 apud Trigo, 2003, p.59), partindo da afirmação de que a prática do turismo é muito mais avançada do que a teoria que aborda essa prática, também argumenta em favor do estabelecimento de uma teoria do turismo, que deverá passar, obrigatoriamente, por uma descrição epistemológica. Para Jovicic (1988,p.3), tal descrição teria viés fenomenológico e seria a "mais apurada e objetiva explanação do turismo como um fenômeno especial, a mais precisa e clara das definições do objeto da pesquisa em turismo". Com essa proposta, considera que aumenta a possibilidade de entendimento da idéia básica do turismo: onde o turismo começa e onde ele termina.

Ao falar de uma epistemologia do turismo não está se falando, necessariamente, de uma ciência do turismo, mas é inegável que, com essa argumentação, a seqüência da idéia é perguntar sobre tal aspecto. Sobre isso é necessário dizer que se enganam aqueles que pensam que o turismo já se constitui em uma ciência. O conceito moderno de ciência é muito maior do que um apanhado de conhecimentos dispersos sobre um determinado assunto.

Uma reflexão sobre a dificuldade de se construir uma "ciência turística" é feita por Boullón (2002, p.20) que, para elaborar uma teoria científica, primeiro é preciso que haja uma série de hipóteses, que constituem o ponto de partida das cadeias dedutivas, cujos últimos elos devem passar pela prova da experiência. Completando-se uma série de hipóteses, satisfatoriamente comprovadas, tem-se a possibilidade de dizer que esse conjunto de idéias nascidas do intelecto e da informação, e, além disso, organizadas sistematicamente, podem constituir os princípios gerais de uma determinada disciplina do saber. Na ciência, todo princípio geral deve ser exato, mas também flexível, de tal maneira que o sistema ideológico possa evoluir quando novas evidências demonstrarem a existência de algum erro no conhecimento e na interpretação da realidade.

Seguindo seu raciocínio, Boullón (2002, p.26) afirma que, não se conhece nenhum pesquisador que tenha alcançado essa sistematização do conhecimento turístico. Tal afirmação leva à conclusão de que o fato de o turismo se tomar uma ciência, é uma realidade ainda a ser alcançada.

A argumentação de Boullón remete a Thomas S. Kuhn, que, em seu maior 
trabalho, A Estrutura das Revoluções Científicas, dentre os vários temas abordados, trata-se de como ocorrem as mudanças de paradigmas que podem ser traduzidos aqui por "alicerces" das ciências e de como são construídas tais ciências. Apesar de ilustrar seu trabalho com exemplos da física, da química e da biologia, suas reflexões podem ser aplicadas também ao campo das ciências sociais e assim, por analogia, ao turismo.

Para Kuhn (2001, p. 219), um paradigma é aquilo que os membros de uma comunidade científica partilham e, inversamente, uma comunidade científica consiste em homens que partilham um paradigma. E Dencker (1998, p.33), amparada pela teoria kuhniana, oferece uma definição mais clara de paradigmas, que são "visões de mundo, conceitos e valores que orientam as investigações, pois permeiam toda a cultura e, por conseguinte, as investigações científicas".

A construção de um modelo ou paradigma, aceito por uma comunidade, dá-se de forma lenta e, quando ocorre, nega quase por completo paradigma considerado até então. E Kuhn (2001, p.38) afirma que "para ser aceita como paradigma, uma teoria deve parecer melhor que suas competidoras, mas não precisa (e de fato isso nunca acontece) explicar todos os fatos com os quais pode ser confrontada"

Para exemplificar, Kuhn (2001, p.41), diz que antes de Newton, todo cientista que fosse estudar a óptica física deveria construir seus fundamentos de estudo, pois ele não se sentia obrigado a aceitar um paradigma posto, uma vez que o mesmo ainda não existia, ou se existia, não tinha grande aceitação por seus pares. E com o turismo, ocorre quase o mesmo. Há algumas teorias, mas os pesquisadores não se sentem obrigados a aceitá-las, e então partem para estudos independentes a fim de formular seus próprios fundamentos. Esse é o caso de autores como Fuster (1971), que propôs um estudo funcionalista do turismo; Leiper (1979), Sessa (1985), Lainé (1985) e Beni (2001), que oferecem uma abordagem estruturalista fundamentada na Teoria Geral de Sistemas, gestada por L. von Bertalanffy; Jafari e Ritchie (1981), que adaptaram o estudo interdisciplinar ao turismo; e Centeno (1992), que sugere a fenomenologia para o estudo do turismo.

Echtner e Jamal (1997, p.876-7), após analisarem a perspectiva de Kuhn, afirmam que o turismo ficará restrito a ser um tópico especializado de pesquisa. Isto é, continuará sendo uma área de estudos dentro de cada disciplina. E vão além: O turismo não é somente um fenômeno pré-paradigmático, mas ele 
também está enterrado em várias e incomensuráveis áreas de estudo e sendo assim, não está em uma posição viável para aspirar a uma nova disciplina.

\subsubsection{Epistemologia do turismo no Brasil}

A discussão sobre a epistemologia do turismo no exterior ocorre há décadas, cerca de quarenta anos, mas só ganhou "corpo" nos últimos vinte anos. No Brasil, por sua vez, dadas ás questões temporais e limites de toda grandeza para o desenvolvimento do conhecimento, faz mais ou menos dez anos que esse assunto vem sendo tratado com a seriedade que merece.

Alguns autores brasileiros, notadamente ligados á instituições de ensino superior, têm abordado essa questão do fundamento científico/filosófico do turismo, tais como:

Luiz Gonzaga Godoi Trigo, foi o primeiro estudioso brasileiro a fazer uma abordagem do turismo, tendo como categoria de análise a pós-modernidade. No livro Turismo e Qualidade: tendências contemporâneas, editado pela primeira vez em 1993, o autor, baseando-se nas definições de sociedade pós-industrial e pósmoderna, insere o turismo como parte integrante, agente e objeto, que influi na sociedade e é influenciado por ela, modificando e sendo modificado a cada avanço ou retrocesso social e afirma que, os fatores que levaram ao desenvolvimento do turismo nestas últimas três décadas foram os mesmos que transformaram profundamente o planeta, seja no âmbito das relações econômicas e políticas, seja no das relações sociais e ambientais. Nas sociedades pós-industriais o turismo, juntamente com o lazer, a cultura, as artes, o esporte e a preocupação com a qualidade de vida, desenvolveu-se a cada ano, ganhando sempre mais espaço nos meios de comunicação, nos negócios internacionais, no interesse e no cotidiano das pessoas.

Apesar de não propor nesse livro um estudo sistemático do turismo como disciplina ou campo, Trigo dá "pistas" de que a criação de uma teoria do turismo deveria, necessariamente, passar pela categoria da pós-modernidade. É isso o que ele faz com maior acuidade no livro, A Sociedade Pós-Industríal e o Profissional do Turismo, fruto de sua tese de doutorado em educação e editado em 1998. 
Neste segundo livro, Trigo aborda de forma verticalizada a temática da pós- modernidade e o turismo. Sua maior contribuição ao estudo epistêmico do fenômeno está no item, "o turismo como ciência", no qual, fundamentado em autores internacionais, faz uma contextualização sobre em que grau está a discussão dessa temática. Sua conclusão é de que "o turismo é uma das especialidades no extenso campo da ciência". Essa não é uma posição inovadora, mas certamente possibilitou - e possibilitará - aos acadêmicos de turismo entrarem em contato com a temática.

Já, Mário Carlos Beni, em sua obra magna, Análise Estrutural do Turismo, propõe uma análise estruturalista do turismo baseada na teoria geral de sistemas e até então, é o único estudioso brasileiro que tentou abordar o fenômeno em toda a sua complexidade. Interessa aqui, entretanto, destacar a visão dele no estabelecimento de uma epistemologia e assim, por sua vez, de uma teoria para o turismo.

Logo de início, o autor deixa claro que acredita que o turismo pode vir a ser uma ciência: É preciso, antes de mais nada, tocar em alguns aspectos da ciência em geral, e mostrar como o turismo vem se firmando como ciência humana e social, ainda que seus efeitos econômicos sejam os que mais se destacam". Explicando tal posição, afirma que apesar de o turismo utilizar os métodos de análise de outras ciências, seu objeto de estudo é próprio, situando - se além de todas elas, como que as carregando, as incorporando e as transformando.

Beni acredita que é importante ampliar a discussão do estabelecimento de bases sólidas para a interpretação crítica do turismo, tanto que, fundamentado em autores contemporâneos e em sua longa experiência com o turismo, propôs a visão sistêmica para abordar o fenômeno. Sua proposta do Sistema de Turismo (Sistur) não se constitui em uma cientifização do turismo, mas, sem dúvida, é um instrumento de referência que um autor brasileiro ofereceu para que os pesquisadores avancem nos estudos referentes à temática.

Quanto à Margarita Barretto, esta também não tem como objeto de estudo a ciência ou a epistemologia do turismo, e, desta forma, assim sua análise apenas trata superficialmente do tema. Em seu Manual de Iniciação ao Estudo do Turismo, editado em 1995, após fazer um "passeio" pelos autores que propuseram estudos para compreender o turismo, a autora indica que a melhor forma de se estudar o turismo é pela fenomenologia, segundo a proposta de Molina. 
Segundo Molina (2000, p.140), a discussão sobre a criação de uma ciência do turismo pode estar indo contra correntes acadêmicas que "estão relativizando a possibilidade de apreensão dos acontecimentos assim como a validade das leis científicas". Apesar disso, considera que "a ciência do turismo precisa crescer para depois ser relativizada, se necessário".

Por outro lado, Mirian Rejowski, em sua tese de doutorado, defendida em 1993, abordou a temática da pesquisa e da produção científica em turismo no Brasil. Para ela, o avanço do turismo está estritamente ligado à pesquisa científica, que é a "mola propulsora" do sistema técnico-científico, estabelecendo um fluxo contínuo de conhecimento".

Em seu livro Turismo e Pesquisa Científica, editado em 1996, a estudiosa, valendo-se de autores como Jafar Jafari, Alfredo Ascanio, Brent Ritchie e Douglas Pearce, entre outros, situa os estudos referentes à construção de uma ciência do turismo. Por não aprofundar o tema (mesmo porque não era seu objeto de estudo), não apresenta nenhum avanço, mas deixa clara a necessidade de se trabalhar com tal assunto.

Esses autores lançaram olhares tangenciais sobre o tema epistemologia do turismo, mas nenhum teve a temática como objeto principal de estudo. A única estudiosa que tratou da epistemologia do turismo de modo direto foi Marutschka Martini Moesch. Ela lança um outro olhar sob a interpretação do conhecimento em turismo. A autora, em seu livro, A Produção do Saber Turístico, percebe que o fenômeno foi estudado até hoje, prioritariamente, com ligação na área econômica, pragmática e consumista. Para provar tal afirmação, citou os inúmeros autores que lançaram as bases teóricas do turismo. Seu maior questionamento é referente à produção do conhecimento do turismo que ensina apenas o "saber fazer", esquecendo-se do "fazer saber", que deve ser a base das ciências sociais.

Ao abordar o tema do turismo no Brasil, aponta que ele é estudado de forma a privilegiar o saber sistemático acerca de um tema específico, ou seja, ele está ligado ao setor produtivo. Quando ocorre um estudo mais teórico do fenômeno, ele acaba sendo reduzido à economia, à geografia, à psicologia, e assim por diante, faltando, portanto, uma visão interdisciplinar do objeto de estudo. Entretanto, como a atividade turística de certo modo, independe das teorias do fenômeno para acontecer, aquela passa a ter supremacia sobre esta.

Para Moesch, a academia no país não está integrada e não partilha dos 
conceitos epistemológicos existentes, ocasionando, assim, uma confusão de terminologias que atrapalha na elaboração de pesquisas. Em sua interpretação, a lógica de mercado adiantou-se à pesquisa científica sobre o tema turismo. Sua definição do turismo deixa transparecer uma preocupação sociológica e um tanto humanista, como pode ser percebido nesta passagem: $O$ turismo é uma combinação complexa de inter-relacionamentos entre produção e serviços, em cuja composição integram-se uma prática social com base cultural, com herança histórica, a um meio ambiente diverso, cartografia natural, relações sociais de hospitalidade, troca de informações interculturais. O somatório desta dinâmica sociocultural gera um fenômeno, recheado de objetividade/subjetividade consumido por milhões de pessoas como síntese: o produto turístico.

$\mathrm{Na}$ busca de superar as limitações das abordagens funcionalista e fenomenológica, Moesch propõe a leitura do turismo a partir dos fundamentos teóricos da dialética-histórico-estrutural, com base nas seguintes categorias: economia, tecnologia, tempo e espaço, sujeito, diversão, ideologia, pósmodernidade, comunicação e imaginário.

Moesch une a visão interdisciplinar e holística do turismo com o processo cíclico de retorno e posterior avanço da abordagem dialética. Entretanto, seu estudo não finaliza a linha de raciocínio; ao contrário, abre um campo ainda maior para a compreensão do fenômeno.

Nas abordagens discutidas, ficou claro que ainda não há um consenso acadêmico do turismo sobre qual é a melhor teoria para estudar o fenômeno. $\mathrm{Na}$ realidade, uma teoria que aborde todos os aspectos do turismo ainda não foi criada. O que existe são aproximações que se tornam importantes, pois juntas, avançando, criticando e sofrendo críticas, construirão a "escada" que levará a uma interpretação mais completa do fenômeno turístico.

Para avançar na discussão de uma epistemologia do turismo, não são necessários apenas trabalhos que tratem da temática, mas um grupo de estudiosos que abordem os mais referidos aspectos do campo. Nesse sentido, apesar do pensamento contrário de alguns críticos brasileiros, notadamente de áreas afins à do turismo, a academia no Brasil avançou significativamente na última década, constituindo-se como a que apresenta o maior número de títulos de turismo da América Latina, superando inclusive o México, país tradicional nessas publicações, conforme confirmam as editoras abaixo relacionadas: Aleph, 
Atlas, Bookman, Chronos, Contexto, Educs, Futura, Manole, Papirus, Roca, Senac São Paulo e Senac Nacional.

São cerca de duzentos títulos que essas editoras lançaram, um número ainda pequeno, se for comparado ao de outras áreas do conhecimento, mas significativo na área de turismo, se for considerado que a maioria dessa produção é dos últimos seis ou sete anos.

\subsection{Educação, Ciência e Sociedade}

A Revolução Científica, o lluminismo e a Revolução Industrial produziram profundas alterações na maneira de ver o mundo, substituindo a visão orgânica predominante até o século XVI por uma concepção mecanicista que se manteve até o início do século $X X$ e cujos efeitos perduram até hoje nas estruturas sociais. Essa visão mecanicista levou a um estreitamento dos valores humanos decorrentes do "empobrecimento ideológico associado com a visão do homem enquanto uma pequena engrenagem de uma máquina" (D' Ambrósio, 1997, p.52 apud Dencker, 2002, p. 23) com os conseqüentes reflexos sobre a educação.

As idéias de progresso, evolução e desenvolvimento industrial enraizaramse na ideologia dos sistemas sociais e influenciaram as estruturas resultantes fazendo com que, desde o século XVIII, o paradigma positivista controlasse a ciência e o pensamento ocidentais, tanto nas ciências físicas quanto nas ciências sociais. Disto resultou um reducionismo do subjetivo para o objetivo, uma vez que a visão positivista recusa explicações da realidade considerada não racional.

No paradigma positivista tem-se o primado do sujeito sobre o objeto, desconsiderando as condições objetivas em que o conhecimento é produzido, o que resulta em uma visão moralizadora que em longo prazo tende a julgar as coisas boas ou más.

A aceleração do processo de industrialização e o desenvolvimento do capitalismo fortaleceram as idéias de fragmentação do trabalho, inclusive o científico e o intelectual, fazendo com que, segundo Ortega y Gasset (1972, p. 171-174 apud Dencker, 2002, p.23), que cada cientista fosse sábio em relação à sua área de conhecimento e ignorante em relação a tudo que não faz parte da 
sua especialidade, criando, assim, uma situação em que seria possível até mesmo prever uma sociedade futura dominada pela barbárie.

Atualmente, a visão mecanicista do universo é contestada e a tendência é a visão do ser humano como a "manifestação de um impulso livre e criativo, ligado de maneira intrínseca ao Universo como um todo" (D' Ambrósio, 1997, p. 52 apud Dencker, 2002, p.25). É possível que esta postura se origine das experiências sociais e da inadequação do paradigma mecanicista para fornecer resposta às novas demandas socioeconômicas de uma ordem social globalizada, do mesmo modo que é viável a hipótese, segundo a qual as alterações que ocorreram nas ciências físicas são os fatores responsáveis pela preparação do novo modo de pensar o real, como questiona Morin (1998 p. 27):

Podemos perguntar, em suma, se em todos os horizontes científicos não se elabora, de modo ainda disperso, confuso, incoerente, embrionário, o que Kuhn denomina revolução científica, a qual, quando é exemplar e fundamental, arrasta uma mudança de paradigmas (isto é, dos princípios de associação/exclusão fundamentais que comandam todo o pensamento e toda a teoria) e, por isso, uma mudança na própria visão de mundo.

Enquanto a ciência clássica trabalhava com a idéia de simplificar a compreensão dos fenômenos por meio da separação e da redução utilizando um enfoque racionalista, o cientista atual depara-se com a noção de complexidade, trabalhando com as teorias de auto-organização, estruturas dissipativas, caos, transdisciplinaridade e outras.

A partir daí, novas formas de compreender os fenômenos ocorridos na ciência, passam a ser aceitas. O homem retoma a dimensão espiritual, amplia a sua visão a partir de múltiplas experiências culturais que exigem sistemas educacionais inovadores e atitudes mentais holísticas que levam à superação de conceitos que não dão conta da realidade atual, cuja natureza multicultural, sob muitos aspectos contraditórios, é aparentemente irracional.

Também, as novas ordens econômicas e sociais dos países inseridos na cultura ocidental baseiam-se em valores, ao mesmo tempo, comparáveis e marcadamente diferentes, resultando, muitas vezes, em comportamentos incompreensíveis de um país para outro. A incorporação de conhecimentos produzidos em contextos culturais específicos para outros contextos culturais 
requer vias apropriadas e mecanismos de adaptação para não causar impactos indesejáveis.

Com isso, a mudança de paradigmas no campo científico requer uma visão da educação, de caráter multicultural, para dar sustentação aos processos criativos cuja base é a diversidade.

É preciso (Morin, 1998, p.31) "que sejam ajudados ou estimulados os processos que permitiriam à revolução científica em curso, realizar a transformação das estruturas de pensamento.".

O ensino deve preparar o homem para pensar a complexidade e integrá-lo na nova realidade na qual os modelos e receitas milagrosas já não existem. O objetivo atual da educação é fazer com que o aluno aprenda a aprender, efetuando uma revisão contínua dos conhecimentos e valores adquiridos. É preciso lembrar que, cada vez mais, o conhecimento é transmitido por diferentes meios, fazendo com que a capacidade crítica seja uma das competências mais importantes a serem desenvolvidas. O aluno deve ser preparado para essa realidade e estimulado para exercitar a liberdade, experimentar novas soluções, buscar alternativas, ser capaz de visualizar as oportunidades que se abrem nos momentos de crise.

$\mathrm{Na}$ última década do século $X X$, observou-se que a escola deixou de preceder a vida profissional para se mesclar a ela, oferecendo formas de reciclagem, centros de educação continuada, treinamento profissional e cursos de especialização dirigidos aos que já integram o mercado de trabalho. Ao mesmo tempo, a escola passa a integrar uma oferta educacional diversificada e pluralista na qual possui um papel destacado, mas não exclusivo. Nessa mudança, observa-se a superação generalizada das fronteiras, seja das disciplinas dos países, ou das áreas de saber, o que requer uma transcendência, uma integração em que a interdisciplinaridade é apenas o início de um processo que deverá levar à (Trigo, 1998, p.159) "transdisciplinaridade, ou seja, algo além das disciplinas em si".

2.3. Ensino Superior, pesquisa científica e interdisciplinaridade.

Os questionamentos quanto à importância da produção cientifica na graduação ampara-se, na oportunidade de inserção do acadêmico a pesquisa, 
bem como, do professor orientador e da Instituição. Conforme a LDB/96 nos artigos 43 a 57, a educação superior tem por finalidade formar profissionais nas diferentes áreas do saber, promovendo a divulgação de conhecimento culturais, científicos e técnicos e comunicando-os por meio do ensino. Objetiva estimular a criação cultural e o desenvolvimento do espírito científico e do pensamento reflexivo, incentivando o trabalho de pesquisa, a investigação científica e promovendo a extensão. Visa divulgar a população a criação cultural e a pesquisa científica e tecnológica geradas nas instituições que oferecem formação em nível superior e produzem conhecimento. (...) Para ser credenciado como universidade, que significa uma instituição pluridisciplinar de formação de quadros profissionais de nível superior, de pesquisa, de extensão, o estabelecimento de educação superior deve caracterizar-se por ter (LDB/96, art.52) "produção intelectual institucionalizada mediante o estudo sistemático dos temas e problemas mais relevantes, tanto do ponto de vista científico e cultural quanto regional e nacional".

A produção de conhecimento por meio de pesquisa exige diversos olhares sobre a mesma realidade pela comunhão de diversos saberes, e isso somente pode ocorrer numa instituição que não se volte apenas para o ensino, como os institutos isolados, mas que seja uma instituição multidisciplinar de ensino, de investigação e de extensão, como a universidade.

O chamado tripé ensino/pesquisa/extensão, que tem englobado as funções que caracterizam uma instituição como universidade, também tem gerado muita polêmica e discordância entre alguns profissionais que trabalham com educação. A literatura sobre o assunto revela uma dissociação cada vez maior entre as funções, principalmente no que se refere ao ensino e à pesquisa.

Muitas discordâncias dessa natureza, têm sido atribuído às dificuldades das instituições de ensino superior e das agências financiadoras de pesquisa em oferecerem subsídios que se possam garantir aos profissionais, uma infraestrutura e uma carga horária adequadas, que contribuam para o desenvolvimento de atividades de pesquisa, principalmente em educação.

Ainda assim, nas instituições de ensino superior, onde a vontade política dos dirigentes e a união de esforços conseguiram conquistar espaços e subsídios para a pesquisa em seus contratos de trabalho com docentes, encontra-se, muitas vezes, um "casamento" de aparências, pois o ensino em sala de aula aparece nitidamente dissociado da pesquisa. 
Outro aspecto muito relevante que, segundo pesquisadores, influencia no como a relação ensino/pesquisa é trabalhada dentro de uma instituição, refere-se às semelhanças e às diferenças existentes entre os sistemas de ensino público e privado e, também, os objetivos de cada instituição. Ressalvadas as exceções, as características mais similares entre as instituições seriam, dentre outras: a pouca integração entre ensino, pesquisa e extensão; o verticalismo nas relações de poder e o distanciamento das universidades à realidade nacional, regional e local.

Dentro desse panorama, as diferenças são reveladas por indicadores como: o ensino público sustentado por verbas públicas que se caracteriza por possuir uma melhor infra-estrutura de apoio ao corpo docente, aos alunos e aos funcionários e pelo destaque que é dado à produção de pesquisas. Já o ensino particular, cuja fonte primordial de financiamento é obtida das mensalidades dos alunos, forma uma quantidade maior de professores para o ensino de primeiro e segundo graus, por meio dos cursos de licenciatura. Esses cursos não dependem de um aparato instrumental nem de maiores investimentos para que funcionem, e se destacam por dar ênfase ao ensino, havendo pouca relação entre graduação e pesquisa.

Aliás, o panorama usual dos cursos de graduação nega, quase sempre, a idéia de ensino com pesquisa. Essa afirmação se confirma quando os professores vêem a pesquisa como atividade de pós-graduação, vinculada à descobertas científicas e tecnológicas e, portanto, fora do alcance de seus alunos, pois exige um rigor científico atingível apenas por mestres e doutores, como se o aluno não fosse, por natureza e desde as séries iniciais, capaz de investigar para satisfazer as dúvidas que possui e para resolver problemas que a sua práxis lhe coloca.

Nesse contexto, coloca-se também, o baixo nível dos alunos das instituições particulares, que perpassam pela dificuldade de concatenar idéias simples e lógicas. Muitos não conseguem no primeiro ano de faculdade desenvolver um texto coerente de 20 linhas, pelo menos. Essa situação não é conseqüência apenas dos equívocos e das deficiências observados na universidade. A escola atual também tem transmitido uma concepção errônea de educação, na qual o que interessa é a memorização e a "decoreba", e não a compreensão e a construção de conhecimentos. Os alunos chegam às universidades sem muitos questionamentos, não possuem o hábito da escrita 
como produção pessoal e nem da leitura como embasamento teórico e, nem mesmo, o hábito de escrever sobre o que lêem ou vice-versa. Dividem seu tempo entre o trabalho profissional e o estudo, ficando este último com o tempo que sobra.

E segundo divulgação da mídia, a educação brasileira, no geral é muito ruim. No final de 2001, dados mostraram que, de um total de 32 países analisados, os estudantes brasileiros ficaram em último lugar em capacidade de leitura. E, com isso, conclui-se que, o que está ocorrendo é a dissociabilidade entre ensino e pesquisa, principalmente nas universidades que possuem o tripé: ensino/pesquisa/extensão. E, o ensino para ser realizado com pesquisa, necessita incorporar os princípios da tarefa investigativa, isto é, assumir os processos metodológicos desta atividade, tendo a dúvida como ponto de partida da aprendizagem. Neste caso, o aluno será o ator principal da ação e é nele que acontecerá o processo de indissociabilidade do ensino e da pesquisa.

Existem dificuldades por parte de alguns professores ao trabalharem o ensino da pesquisa (em disciplinas específicas), bem como, o ensino vinculado, associado à pesquisa, seja na graduação ou em qualquer outro nível de ensino. Isso porque o modelo epistemológico que rege muitos cursos, até hoje, é baseado na concepção positivista de ciência, que vê o conhecimento como verdade, algo certo, acabado, capaz de ser transmitido por meio de técnicas e modelos pedagógicos, e isso passa a influir (e muito) na maneira de se organizar o próprio conhecimento e o modo de trabalhar em aula.

Essa dificuldade em se trabalhar o ensino da pesquisa é percebida claramente nos currículos dos cursos de graduação, que deixam a iniciação científica a cargo de disciplinas distintas com denominações variadas e que possuem pouca ou quase nenhuma comunicação com as demais disciplinas que integram o currículo total do curso. Também, é percebida essa deficiência quando os próprios professores, responsáveis pelo ensino da pesquisa (titulares de tais disciplinas), não estão vinculados a projetos de pesquisa, ou até mesmo se prendem ao seguimento de manuais, camisasde-força que privilegiam a normalização do pesquisar.

Outro fato comum que ocorrem entre os professores, é a exigência de um trabalho monográfico ou a elaboração de um projeto de pesquisa, no final dessas 
disciplinas, apenas com a finalidade de dar nota e testar se o aluno aprendeu ou não a pesquisar, como que num faz-de-conta, numa tentativa de encobrir (mas não acabar), a dissociação entre ensino e pesquisa, concebendo, assim, através dessas atividades, que o aluno tenha produzido conhecimento científico. Evidentemente, sem recriminar essas atividades, a monografia e os projetos de pesquisa, quando bem-conduzidos, dentro de uma concepção de postura pesquisante, podem ser um excelente recurso para iniciar o aluno na atividade científica, principalmente se incluir neles uma dimensão de trabalho de campo bem-orientado e elaborado.

A forma como a pesquisa é trabalhada em muitos cursos de graduação, em disciplinas que se destinam a esse fim, faz com que os alunos, muitas vezes, encontrem grandes dificuldades em elaborar trabalhos que exijam uma organização sistemática e uma elaboração mais aprofundada. Tais dificuldades os induzem a repetir as noções de pesquisa que tiveram nos ensinos fundamental e médio, onde a experiência é entendida como um experimento, e a pesquisa como sendo uma cópia (pescópia) do que outros autores já descobriram ou da própria realidade já instituída.

Neste contexto, propõe-se a interdisciplinaridade que conforme discorre Dencker (2002, p.72): "A origem do projeto interdisciplinar coloca-se no contexto da pós-modernidade, respondendo à necessidade de superação dos entraves causados pelo paradigma de fragmentação disciplinar atribuído ao racionalismo. E ainda, (2002, p.73), "a interdisciplinaridade coloca em confronto valores e conceitos, permitindo o desenvolvimento de uma consciência crítica e incentivando a formulação de soluções criativas."

Como indica Barbosa (1979, p.61 apud Dencker, 2002, p. 73):

A função da interdisciplinaridade não é comunicar ao indivíduo uma visão integrada de todo o conhecimento, mas desenvolver nele um processo de pensamento que o torne capaz de, frente a novos objetos de conhecimento, buscar uma nova síntese.

Continuando com as colocações de Dencker em que procurando atingir este resultado, multiplicam-se os trabalhos de abordagem qualitativa fundamentado na ação e na intervenção no campo da educação, centrando o foco no aluno, visando a construção do saber científico e o desenvolvimento do método de forma mais flexível, mas nem por isso menos preciso. 
Do ponto de vista teórico, Fazenda (1994, p.27 apud Dencker, 2002, p. 73) diz que:

$$
\begin{aligned}
& \text { não é possível partir-se de um quadro teórico organizado para } \\
& \text { procedermos a uma análise que avance e redimensione as práticas } \\
& \text { escolares no sentido da interdisciplinaridade. É necessário que esse } \\
& \text { quadro teórico seja construído na medida em que o objeto a ser } \\
& \text { analisado - o educacional - assim o exigir. }
\end{aligned}
$$

Dentro dessa perspectiva é apresentada a construção de uma proposta viável no contexto das universidades, que permite a implantação de uma ação educativa orientada para práticas integradoras, utilizando o espaço criado para práticas interdisciplinares.

A proposta centra-se na realização de projetos conjuntos de pesquisa que reúnem o referencial teórico das diferentes disciplinas para dar fundamento às pesquisas de campo e análise dos dados. Embora o ponto de partida seja o levantamento bibliográfico, o objetivo não é a elaboração de uma monografia a partir de consultas a livros e outras fontes documentais.

A idéia é trabalhar a produção do conhecimento juntamente com o aluno, envolvendo todos os professores dentro de uma perspectiva crítica que estimule a reflexão. A universidade é o espaço de produção do conhecimento e não de simples reprodução do mesmo. 
A metodologia turística é o "Conjunto de métodos empíricos experimentais, seus procedimentos, técnicas e táticas para ter um conhecimento científico, técnico ou prático dos fatos turísticos."

Organização Mundial de Turismo

\section{METODOLOGIA}

O trabalho de pesquisa é norteado pelos pressupostos filosóficos do autor e que, definido, orientará a escolha do método, metodologia e técnicas a utilizar na pesquisa que se propõe a realizar.

Os objetivos desta pesquisa foi de levantar informações da produção de conhecimento dos trabalhos de final de curso. Trata-se de uma pesquisa qualitativa e utiliza como instrumento de coleta de dados, entrevista informal e por acessibilidade com os professores orientadores e os trabalhos de final de curso.

A metodologia utilizada teve como critério quanto aos meios de investigação, a pesquisa bibliográfica - bibliografias pertinentes ao tema - e a documental - 18 trabalhos de final de curso, apresentados pelas turmas que concluíram o curso de turismo no período de junho de 2002 a junho de 2003, da Faculdade Cambury e Universidade Católica de Goiás.

A amostra utilizada foi por acessibilidade. A Universidade Católica, no período de realização da pesquisa, não tinha os trabalhos disponibilizados em sua biblioteca por estar em reforma, e a Faculdade Cambury não libera seus trabalhos para leitura fora de suas dependências. Diante da dificuldade de conseguir os trabalhos para a realização da pesquisa, procurou-se professores que orientaram e/ou participaram das bancas no período proposto para pesquisa e, através dos mesmos, conseguiu-se 18 trabalhos que foram o objeto de estudo desta pesquisa.

Através de uma análise da estrutura geral desses trabalhos, chegou-se à conclusão que tema, problemas, hipóteses, objetivos, metodologia proposta e conclusão estão destoados uns dos outros.

Para melhor compreensão dos trabalhos a partir dessas colocações, fezse um "Quadro de Análise" considerando título/tema, problematização, hipóteses, objetivos e metodologia. A partir também dessas informações, atendendo ao propósito deste projeto de analisar a produção de conhecimento nos cursos de 
turismo, escolheu-se 3 trabalhos, cada um de uma orientadora, levando-se em consideração os seguintes itens:

- Relevância dos temas para o turismo;

- Coerência no desenvolvimento dos trabalhos com o tema, problema, hipóteses e suas variáveis e objetivos propostos;

- A metodologia utilizada para pesquisa;

- A fundamentação teórica;

- A interdisciplinaridade;

- A teoria e a prática;

- Como o autor se coloca no trabalho.

Com a definição desses critérios e do quadro de análise, procedeu-se a uma análise criteriosa dos 3 trabalhos escolhidos, resguardando, porém, 0 entendimento da limitação referente à construção dos trabalhos de final de curso da graduação. 
Ensinar não pode nem deve significar outra coisa que revelar a cada um tudo o que ele é e tudo o que pode.

\section{OS TRABALHOS OBSERVADOS}

J. Guéhenno

Entende-se que a produção do conhecimento requer pesquisas sob vários olhares, amparados em diversos saberes e, principalmente, no método científico, ressaltando conforme coloca Demo (1989, p. 16),

o maior problema da ciência não é o método, mas a realidade. Como esta não é evidente, nem coincidem completamente, a idéia que temos da realidade e a própria realidade, é preciso primeiro colocar esta questão: o que consideramos real?

Os trabalhos analisados perpassam por diversas áreas e saberes embasados na teoria/prática. Foram desenvolvidos utilizando-se diversos métodos de pesquisa, pois, segundo Richardson (1999, p.326), "o tipo de pesquisa a realizar depende dos objetivos do trabalho, da natureza do problema e das possibilidades do pesquisador."

Através do exame dos trabalhos constatou-se a diversidade dos tipos de pesquisas realizadas, de metodologias, temas e segmentos de turismo abordados. Verificou-se que os professores orientadores quase sempre são os mesmos, embora com formação diversificada, conforme descrito abaixo:

- uma professora, que orientou trabalhos nas duas IES, tem bacharelado em direito e relações públicas, especialização em marketing e mestrado em administração;

- outra, que orientou somente em uma IES, tem bacharelado e licenciatura em história, especialização em cultura, memória e linguagem, mestrado em história; é doutoranda em história.

- a outra, que também orientou somente em uma IES, tem bacharelado em turismo e hotelaria e mestrado em hotelaria.

Não é possível formar um parecer ou mesmo questionar se professores orientadores, com formações tão diversas aos temas propostos, podem ou não orientar com propriedade e conhecimento esses trabalhos. A vivência da orientação perpassa por diversas dificuldades, desde as regras e normas das Instituições de Ensino que, muitas vezes, são castradoras e 
desmotivadoras, como ainda a acanhada desin/formação do aluno que não tem por hábito a leitura, a pesquisa e, muito menos, a construção de textos.

Entretanto, a contribuição do professor orientador é crucial no desenvolvimento desses trabalhos. Além disso, compreende-se que, apesar de muitos trabalhos quando finalizados não atenderem às exigências de normas metodológicas e de conteúdo, o orientador os defenda, pois vivenciou as dificuldades e o crescimento desses alunos - posicionamento fundamental para que estes jovens encarem o mercado com mais confiança.

É interessante salientar que dos 18 (dezoito) trabalhos consultados, uma mesma professora participou como membro da banca na apresentação de 9 (nove) trabalhos, isto é, em $50 \%$ das bancas.

Das duas instituições pesquisadas e que já formaram turmas no período proposto, os trabalhos de final de curso não seguem a mesma linha. $\mathrm{Na}$ Universidade Católica de Goiás, o trabalho é um relatório do estágio realizado em alguma empresa e/ou qualquer entidade ligada ao turismo. Na Faculdade Cambury, o trabalho não está vinculado ao estágio, pois a mesma exige um relatório de estágio à parte, podendo ser o trabalho de final de curso qualquer tipo de pesquisa como histórica, exploratória, descritiva, explicativa - enquetes, experimentos, quase experimentos, estudos de casos - pesquisa-ação, ficando, portanto, à escolha do aluno com a orientação do professor. 


\section{QUADRO DE ANÁLISE DOS TRABALHOS}

\begin{tabular}{|c|c|c|c|c|}
\hline TEMA & PROBLEMA & HIPÓTESES & OBJETIVOS & METODOLOGIA \\
\hline $\begin{array}{l}\text { O Mundo Virtual de } \\
\text { uma Agência de } \\
\text { Viagem em Turismo }\end{array}$ & $\begin{array}{l}\text { Qual é a ferramenta mais viável, } \\
\text { para aliviar o fluxo excessivo de } \\
\text { clientes, a procura de } \\
\text { informações básicas, na Rio } \\
\text { Verde Viagens e Turismo? }\end{array}$ & $\begin{array}{l}\text { A utilização de uma página na } \\
\text { Internet possibilitará, a Agência de } \\
\text { turismo, atendimento on-line, } \\
\text { seguro, rápido. Além de oferecer } \\
\text { um serviço de qualidade, moderno } \\
\text { e com maior comodidade aos } \\
\text { clientes, possibilitando a a } \\
\text { diminuição do fluxo de pessoas } \\
\text { nas dependências físicas da } \\
\text { empresa. }\end{array}$ & $\begin{array}{l}\text { Geral: } \\
\text { Desenvolver uma ferramenta para aliviar o } \\
\text { fluxo de pessoas que entram na agência } \\
\text { apenas em busca de informações básicas. } \\
\text { Específicos: } \\
\text {-Identificar potencial tecnológico da Agência } \\
\text { Rio Verde Viagens e Turismo, visando um } \\
\text { crescimento dentro do mercado regional, } \\
\text { para quem sabe no futuro realizar } \\
\text { transações comerciais a nível mundial. } \\
\text { - Criar uma ferramenta virtual capaz de } \\
\text { solucionar o problema detectado pela } \\
\text { Agência Rio Verde Turismo. }\end{array}$ & $\begin{array}{l}1^{\text {a }} \text { etapa - pesquisa exploratória- } \\
\text { "em profundidade "in locu" (sic), } \\
\text { dentro da organização; } \\
2^{\mathrm{a}} \text { etapa - estudo de caso - } \\
\text { "levantamento e análise através de } \\
\text { "Estudos de Casos" como uma } \\
\text { estratégia de pesquisa permitindo o } \\
\text { estudo de fenômenos dentro de seu } \\
\text { contexto, através de observação } \\
\text { participante, e em fontes } \\
\text { secundárias. em falla }\end{array}$ \\
\hline $\begin{array}{l}\text { Perfil, Motivação e } \\
\text { Percepção do turista } \\
\text { que visitou a Cidade } \\
\text { de Goiás durante a } \\
\text { Semana Santa no ano } \\
\text { de } 2002\end{array}$ & $\begin{array}{l}\text {-Quem são os turistas que } \\
\text { visitaram a Cidade de Goiás } \\
\text { durante a Semana Santa no ano } \\
\text { de 2002; } \\
\text { Quais os motivos da escolha da } \\
\text { Cidade de Goiás como destino } \\
\text { turístico; } \\
\text { Qual a percepção do turista em } \\
\text { relação à Cidade de Goiás. }\end{array}$ & $\begin{array}{l}\text {-Os turistas que visitaram a Cidade } \\
\text { de Goiás durante a Semana Santa } \\
\text { no de 2002, em sua maioria são } \\
\text { provenientes de Goiânia, } \\
\text { hospedam em casa de amigos ou } \\
\text { parentes, seu gasto médio por dia } \\
\text { é de R\$ 40,00 (quarenta reais), } \\
\text { possui nível superior de } \\
\text { escolaridade e sua faixa etária é } \\
\text { de } 22 \text { a } 40 \text { anos; } \\
\text {-A principal motivação que levou } \\
\text { os turistas a visitarem a Cidade de } \\
\text { Goiás durante a Semana Santa do } \\
\text { ano de } 2002 \text { foi vivenciar culturas } \\
\text { novas e diferentes; } \\
\text {-Os turistas que visitaram a Cidade } \\
\text { de Goiás durante a Semana Santa } \\
\text { no ano de 2002, em sua maioria } \\
\text { consideraram como atrativos } \\
\text { turísticos; } \\
\text {-Os turistas que visitaram a Cidade } \\
\text { de Goiás durante a Semana Santa } \\
\text { no de 2002, em sua maioria } \\
\text { consideraram como regular as } \\
\text { facilidades turísticas; } \\
\text { Os turistas que visitaram a Cidade } \\
\text { de Goiás durante a Semana Santa }\end{array}$ & $\begin{array}{l}\text { Geral: } \\
\text {-Conhecer os turistas que visitaram a } \\
\text { Cidade de Goiás durante a Semana Santa } \\
\text { no ano de 2002, com vistas à identificação } \\
\text { de seu perfil, motivação e percepção; } \\
\text { Específicos: } \\
\text {-Traçar o perfil do turista que visitou a } \\
\text { Cidade de Goiás durante a Semana Santa, } \\
\text { por meio de critérios bio-sócio- } \\
\text { demográficos; } \\
\text {-Identificar nos turistas as motivações da } \\
\text { escolha da Cidade de Goiás como destino } \\
\text { turístico na Semana Santa; } \\
\text {-Conhecer a percepção do turista em } \\
\text { relação à cidade visitada. }\end{array}$ & $\begin{array}{l}\text { Tipo de pesquisa - método de } \\
\text { abordagem utilizado foi dedutivo, } \\
\text { seguindo critérios de forma } \\
\text { exploratória e descritiva quanto aos } \\
\text { fins e realizada pesquisa de campo } \\
\text { quanto aos meios de investigação. } \\
\text {-Instrumentos de coleta de dados: a } \\
\text { pesquisa foi realizada mediante a } \\
\text { aplicação de } 320 \text { formulários } \\
\text { estruturados com perguntas } \\
\text { fechadas. } \\
\text {-A análise dos dados foi feita de } \\
\text { forma descritiva, por meio de } \\
\text { gráficos, confrontando o referencial } \\
\text { teórico levantado sobre o perfil, } \\
\text { motivação e percepção, e sobre os } \\
\text { resultados encontrados. }\end{array}$ \\
\hline
\end{tabular}




\begin{tabular}{|c|c|c|c|c|}
\hline & & $\begin{array}{l}\text { no ano de } 2002 \text {, em sua maioria } \\
\text { consideraram como ruim a } \\
\text { acessibilidade turística. }\end{array}$ & & \\
\hline $\begin{array}{lr}\text { Transporte aéreo } & \text { de } \\
\text { passageiros: } & \text { a } \\
\text { integração } & \text { do } \\
\text { passageiro em uma } \\
\text { cultura de segurança } \\
\text { de vôo } \\
\text { procedimentos } \\
\text { segurança atinentes, } \\
\text { de modo especial aos } \\
\text { passageiros. }\end{array}$ & $\begin{array}{l}\text { Qual é o nível de } \\
\text { conscientização dos usuários do } \\
\text { transporte aéreo a respeito da } \\
\text { segurança de vôo e como o } \\
\text { conhecimento desses usuários } \\
\text { sobre o seu papel na questão de } \\
\text { segurança de vôo pode diminuir } \\
\text { o número de acidentes e, } \\
\text { principalmente, melhorar as } \\
\text { condições da viagem, em } \\
\text { conforto e bem estar dos } \\
\text { usuários do transporte aéreo? }\end{array}$ & $\begin{array}{l}\text {-O conhecimento dos usuários } \\
\text { sobre o seu papel na questão de } \\
\text { segurança de vôo pode diminuir o } \\
\text { número de acidentes e é } \\
\text { determinante de certas condições } \\
\text { da viagem, podendo levar ao maior } \\
\text { conforto e bem estar do } \\
\text { passageiro; } \\
\text {-Atualmente os usuários ainda não } \\
\text { possuem ou não põem em prática } \\
\text { dos conhecimentos necessários } \\
\text { sobre questões de segurança de } \\
\text { vôo, que dizem respeito a ele, } \\
\text { diretamente (como, o porte de } \\
\text { telefone celular e aparelhos eletro- } \\
\text { eletrônicos). }\end{array}$ & $\begin{array}{l}\text { Geral: } \\
\text { Conhecer a realidade do usuário do } \\
\text { transporte aéreo, sob o aspecto segurança; } \\
\text { Específicos: } \\
\text {-verificar o que o usuário considera } \\
\text { necessário conhecer sobre o assunto; } \\
\text {-verificar de quais informações o usuário se } \\
\text { considera conhecedor; } \\
\text {-verificar se o passageiro considera que o } \\
\text { excesso de informações a respeito de } \\
\text { segurança de vôo pode causar pânico a } \\
\text { bordo; } \\
\text {-contribuir para melhor conhecimento e } \\
\text { compreensão do papel dos usuários do } \\
\text { transporte aéreo sobre a questão da } \\
\text { segurança. }\end{array}$ & $\begin{array}{l}\text { Pesquisa exploratória } \\
\text { levantamento acerca do tema } \\
\text { "Transporte aéreo de passageiros e } \\
\text { segurança de vôo", enfocando } \\
\text { conteúdos } \\
\text { procedimentos refentes de segurança } \\
\text { atinentes de modo especial aos } \\
\text { passageiros, escolhido através de } \\
\text { fontes formais (livros e revistas } \\
\text { constantes das referências } \\
\text { bibliográficas ), e informais } \\
\text { (conversas com funcionários civis e } \\
\text { militares do Aeroporto Santa } \\
\text { Genoveva-Goiânia). A pesquisa foi } \\
\text { realizada com aplicação de 40 } \\
\text { questionários com perguntas } \\
\text { fechadas.. } \\
\text { - }\end{array}$ \\
\hline \begin{tabular}{lll|} 
A Dinâmica & das \\
Visitas Técnicas & das \\
IES de Goiânia &
\end{tabular} & 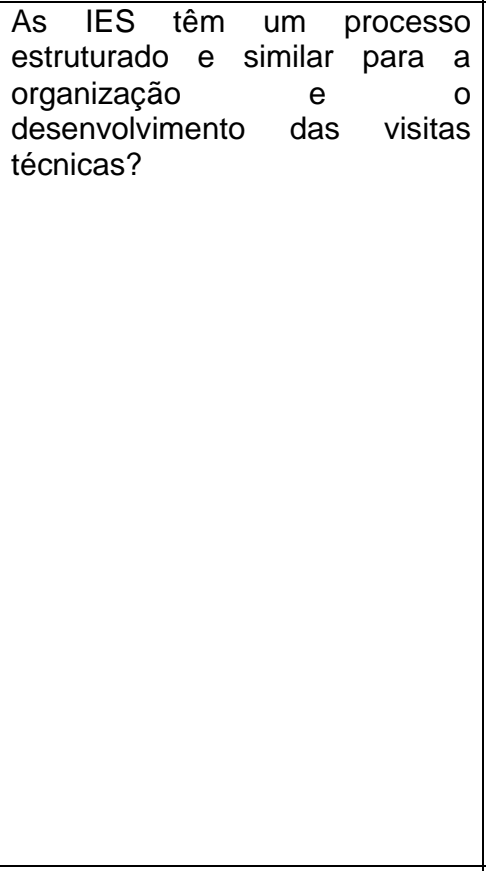 & $\begin{array}{l}\text {-A participação dos alunos na } \\
\text { prática (organização e escolha do } \\
\text { local) da visita técnica é parcial, } \\
\text { tanto em relação ao quantitativo } \\
\text { existente em sala quanto ao } \\
\text { exercício em campo; } \\
\text { - A visita técnica pelo seu caráter e } \\
\text { envolvimento teórico e prático que } \\
\text { resulta em produção de técnicas e } \\
\text { atividades de cunho } \\
\text { profissionalizante, diferencia-se, } \\
\text { assim, da conceituação de turismo } \\
\text { cultural, científico, de estudos ou } \\
\text { educacional; } \\
\text {-As IES não têm um processo } \\
\text { estruturado e similar para } \\
\text { organização e desenvolvimento } \\
\text { das visitas técnicas. }\end{array}$ & $\begin{array}{l}\text { Geral: } \\
\text { Identificar nas Instituições de Ensino } \\
\text { Superior - IES (faculdades, universidades), } \\
\text { localizadas na cidade de Goiânia nos } \\
\text { cursos referentes à área de turismo e de } \\
\text { hotelaria, a dinâmica da realização de } \\
\text { visitas técnicas, considerando o período de } \\
1998 \text { até 2001. } \\
\text { Específicos: } \\
\text {-Catalogar as faculdades e universidades } \\
\text { que possuem cursos na área de turismo e } \\
\text { de hotelaria; } \\
\text {-Verificar o número de visitas técnicas } \\
\text { realizadas, semestralmente, pelas IES; } \\
\text {-Fazer um breve e condensado comparativo } \\
\text { entre a visita técnica e os tipos ou } \\
\text { segmentação de turismo similares (cultural, } \\
\text { científico, de estudos ou educacional) de } \\
\text { acordo com as informações adquiridas; } \\
\text {-Identificar as cidades e atrativos escolhidos } \\
\text { para a prática da visita técnica; } \\
\text {-Demonstrar, em gráficos e ou planilhas, a } \\
\text { participação de estudantes e professores } \\
\text { que participaram das visitas técnicas. } \\
\end{array}$ & $\begin{array}{l}\text { Tipos de pesquisa: } \\
\text {-Exploratória e ou bibliográfica; } \\
\text {-Descritiva } \\
\text { Instrumentos: serão utilizados } \\
\text { questionários, ficha de coleta de } \\
\text { dados e informações. } \\
\text {-Tabulação- das questões abertas e } \\
\text { fechadas e das informações e dados } \\
\text { de caráter empírico. }\end{array}$ \\
\hline Perfil e satisfação dos & Os funcionários da área de & Os funcionários da área de & Geral: & O método de pesquisa utilizado será \\
\hline
\end{tabular}




\begin{tabular}{|c|c|c|c|c|}
\hline \begin{tabular}{|l|} 
funcionários da área \\
de governança do San \\
Marino Suíte Hotel.
\end{tabular} & \begin{tabular}{l}
\multicolumn{4}{l}{ governança do San Marino Suíte } \\
Hotel têm exercido suas \\
atividades com motivação e \\
estão satisfeitos com ro \\
desempenho de sua área e da \\
empresa?
\end{tabular} & $\begin{array}{l}\text { governança do San Marino Suíte } \\
\text { Hotel não tem exercido com } \\
\text { satisfação suas atividades o que } \\
\text { tem proporcionado uma diminuição } \\
\text { na produtividade dessa área. }\end{array}$ & $\begin{array}{l}\text { Conhecer o perfil e a satisfação dos } \\
\text { funcionários da área de governança do San } \\
\text { Marino Suíte Hotel; } \\
\text { Específicos: } \\
\text {-Levantar dados e informações dos } \\
\text { funcionários da área de governança, sobre } \\
\text { a estrutura e funcionamento do hotel nessa } \\
\text { área; } \\
\text {-Obter informações sobre a política de } \\
\text { recursos humanos do hotel; } \\
\text { Identificar a relação motivação X } \\
\text { desempenho (produtividade) da área de } \\
\text { governança do Sana Marino Suíte Hotel; } \\
\text {-Conhecer o histórico do hotel; } \\
\text { Levantar o perfil do profissional da área de } \\
\text { governança do hotel. }\end{array}$ & 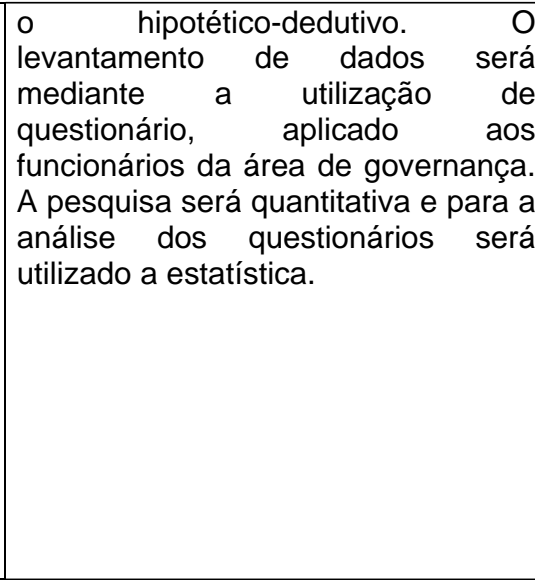 \\
\hline 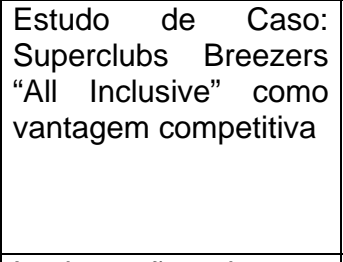 & 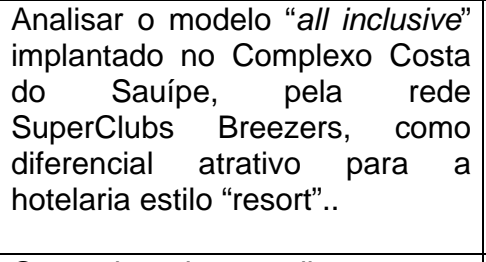 & & $\begin{array}{l}\text { Apresentar o "all inclusive" como principal } \\
\text { vantagem competitiva do Breezers, } \\
\text { mostrando que este benefício é valorizado } \\
\text { pelos seus hóspedes, o que se reflete nas } \\
\text { suas taxas de ocupação, e } \\
\text { fundamentalmente no grau de satisfação } \\
\text { dos clientes. }\end{array}$ & $\begin{array}{l}\text { Método de abordagem dedutivo, por } \\
\text { ser o que melhor engloba e embasa } \\
\text { a estratégia de pesquisa escolhida: } \\
\text { estudo de caso. Utilizou-se como } \\
\text { auxílio, o método estatístico e o } \\
\text { histórico. }\end{array}$ \\
\hline $\begin{array}{|lr|}\text { Implantação de um } \\
\text { Departamento } & \text { de } \\
\text { Turismo no Estádio } \\
\text { Serra Dourada }\end{array}$ & $\begin{array}{l}\text { O serviço de atendimento aos } \\
\text { visitantes prestados pelos } \\
\text { funcionários do Estádio Serra } \\
\text { Dourada tem atendido às } \\
\text { necessidades e expectativas do } \\
\text { seu público visitante? }\end{array}$ & $\begin{array}{l}\text {-O Estádio Serra Dourada não tem } \\
\text { prestado um serviço eficaz de } \\
\text { atendimento ao seu visitante; } \\
\text {-O Estádio Serra Dourada não } \\
\text { disponibiliza em seu quadro de } \\
\text { funcionários, de um profissional } \\
\text { qualificado para acompanhar os } \\
\text { visitantes e prestar os } \\
\text { esclarecimento necessários em } \\
\text { relação à sua história e a sua infra- } \\
\text { estrutura. }\end{array}$ & $\begin{array}{l}\text { Geral: } \\
\text {-Coletar opiniões dos visitantes do Estádio } \\
\text { Serra Dourada em relação a sua satisfação } \\
\text { com o serviço de atendimento prestado e se } \\
\text { a prestação desse serviço tem atendido às } \\
\text { expectativas desses visitantes; } \\
\text { - Coletar informações do corpo funcional } \\
\text { sobre se o Estádio Serra Dourada tem } \\
\text { prestado um serviço de atendimento eficaz } \\
\text { ao seu visitante. } \\
\text { Específicos: } \\
\text {-Identificar o nível de satisfação dos } \\
\text { visitantes em relação aos serviços de } \\
\text { atendimento disponibilizados pelo Estádio } \\
\text { Serra Dourada a esse público; } \\
\text {-Identificar as necessidades prementes do } \\
\text { público visitante do Estádio Serra Dourada; } \\
\text {-Conhecer o perfil dos visitantes do Estádio; } \\
\text {-Coletar informações do corpo funcional } \\
\text { sobre o serviço prestado ao visitante do } \\
\text { Estádio Serra Dourada; } \\
\text {-Obter dados seguros capazes de servir } \\
\text { como referencial na elaboração de um }\end{array}$ & $\begin{array}{l}\text { Pesquisas exploratória e descritiva. } \\
\text { A pesquisa será realizada mediante } \\
\text { questionários estruturados, com uma } \\
\text { amostragem de } 50 \text { questionários. } \\
\text { Os resultados obtidos serão } \\
\text { demonstrados por meio de gráficos, } \\
\text { tabelas e análise qualitativa dos } \\
\text { dados. }\end{array}$ \\
\hline
\end{tabular}




\begin{tabular}{|c|c|c|c|c|}
\hline & & & $\begin{array}{l}\text { Plano de Ação que possa atender as } \\
\text { necessidades do público ligado ao estádio } \\
\text { Serra Dourada. }\end{array}$ & \\
\hline $\begin{array}{l}\text { Turismo Sustentável e } \\
\text { Certificação } \\
\text { Ambiental: } \\
\text { indicadores eficientes } \\
\text { para } \\
\text { desenvolvimento do } \\
\text { Estado do Acre }\end{array}$ & $\begin{array}{l}\text { O pioneirismo do processo de } \\
\text { certificação ambiental ocorrido } \\
\text { no Seringal Cachoeira (Xapuri- } \\
\text { AC), contribui para o } \\
\text { desenvolvimento do turismo } \\
\text { sustentável no Estado do Acre? }\end{array}$ & $\begin{array}{|lr|}\text {-O desenvolvimento do turismo } \\
\text { para o Estado do Acre deve estar } \\
\text { vinculado a iniciativas locais de } \\
\text { reestruturação do modo de } \\
\text { extração de seus recurso naturais } \\
\text { baseados em princípios de } \\
\text { sustentabilidade ambiental; } \\
\text {-O processo de certificação da } \\
\text { madeira no Seringal Cachoeira } \\
\text { admite o reconhecimento da } \\
\text { importância de processos de } \\
\text { certificação para a prática de } \\
\text { atividades que impulsionem o } \\
\text { turismo no Estado do Acre; } \\
\text { A busca da sustentabilidade } \\
\text { através de um novo paradigma de } \\
\text { desenvolvimento econômico } \\
\text { aparece como uma alternativa ao } \\
\text { exercício do turismo sustentável no } \\
\text { Estado do Acre. }\end{array}$ & $\begin{array}{l}\text { Geral: } \\
\text {-Demonstrar que o exercício do turismo no } \\
\text { Estado do Acre está vinculado a uma } \\
\text { reestruturação econômica baseada na } \\
\text { exploração sustentada de seus recursos } \\
\text { naturais. } \\
\text { Específicos: } \\
\text { - Demonstrar a importância do a do } \\
\text { desenvolvimento sustentável como um novo } \\
\text { paradigma a ser administrado na execução } \\
\text { de projetos, programas, etc.; } \\
\text {-Identificar a tendência do mercado } \\
\text { consumidor utilizar produtos que obtenham } \\
\text { um certificado de origem florestal ou "selo } \\
\text { verde"; } \\
\text {-Caracterizar a iniciativa do processo de } \\
\text { certificaçãa ambiental ocorrido no Seringal } \\
\text { Cachoeira, no município de Xapuri; } \\
\text {-Mostrar que a certificação desempenha } \\
\text { papel relevante à atuaçâo sustentada dos } \\
\text { municípios e estados amazônicos como } \\
\text { fonte de riqueza econômica e ao a } \\
\text { desenvolvimento do turismo; } \\
\text {-Compatibilizar o novo modelo de } \\
\text { desenvolvimento econômico do Acre, } \\
\text { baseado na ótica da certificação, com a } \\
\text { prática do turismo sustentável. }\end{array}$ & $\begin{array}{l}\text { Quanto aos fins a pesquisa será } \\
\text { descritiva e explicativa. } \\
\text { Quanto aos meios será bibliográfica } \\
\text { e estudo de caso. } \\
\text { Para a coleta de dados utilizamos de } \\
\text { entrevistas informais, observação } \\
\text { participante e, principalmente, } \\
\text { material escrito sobre o assunto e/ou } \\
\text { fatos ocorridos no local. }\end{array}$ \\
\hline $\begin{array}{l}\text { Recreação e Lazer } \\
\text { para Escola }\end{array}$ & $\begin{array}{l}\text { Como melhorar o processo de } \\
\text { Recreação e Lazer do Colégio } \\
\text { Estadual Polivalente Professor } \\
\text { Goiany Prates, considerando } \\
\text { suas estruturas e tornando-o } \\
\text { compatível com as reais } \\
\text { necessidades de seus alunos? }\end{array}$ & & $\begin{array}{l}\text { Geral; } \\
\text { Levantar o perfil e o nível de interesse e } \\
\text { necessidades dos alunos e do colégio em } \\
\text { estudo, para a elaboração do Plano de } \\
\text { Ação. } \\
\text { Específico: } \\
\text {-Identificar as características estruturais do } \\
\text { Colégio; } \\
\text {-Identificar o perfil dos alunos e suas } \\
\text { motivações quanto as atividades de } \\
\text { recreação; } \\
\text {-Identificar e observar as atividades de } \\
\text { recreação desenvolvidas pelo Colégio; } \\
\text {-Elaborar e aplicar um questionário de } \\
\text { pesquisa; dados para determinar as as } \\
\text {--Coletar de de }\end{array}$ & $\begin{array}{l}\text { Pesquisa exploratória e descritiva. } \\
\text { A coleta de dados será com } \\
\text { aplicação de questionários com uma } \\
\text { amostragem de } 50 \text { alunos, definido } \\
\text { conforme fórmula estatística. }\end{array}$ \\
\hline
\end{tabular}




\begin{tabular}{|c|c|c|c|c|}
\hline & & & $\begin{array}{l}\text { estratégias a serem propostas no Plano de } \\
\text { Ação, estando estas de acordo com a } \\
\text { realidade do Colégio. }\end{array}$ & \\
\hline $\begin{array}{l}\text { Captação de Eventos } \\
\text { em Conventios \& } \\
\text { Visitors Bureaux }\end{array}$ & $\begin{array}{l}\text { Qual o papel do Convention } \\
\text { Bureaux na captação de eventos } \\
\text { e na de geração de empregos e } \\
\text { renda que é um canal eficaz } \\
\text { para beneficiar a capital goiana } \\
\text { e expandir o setor hoteleiro e } \\
\text { todos segmentos da área de } \\
\text { turismo. }\end{array}$ & $\begin{array}{l}\text { Captação de Eventos Aplicada aos } \\
\text { Conventions Bureaux reforça a } \\
\text { idéia de geração de empregos e } \\
\text { renda que é um canal eficaz para } \\
\text { beneficiar a capital goiana e } \\
\text { expandir o setor hoteleiro e todos } \\
\text { segmentos da área de turismo. }\end{array}$ & $\begin{array}{l}\text { Geral: } \\
\text {-Apresentar um dos elementos que } \\
\text { intervém na gestão do mercado de eventos, } \\
\text { o Convention \& Visitors Bureaux. } \\
\text { Específico: } \\
\text {-Traçar o perfil dos conventions bureaux } \\
\text { para identificação de seu processo de } \\
\text { captação de eventos. }\end{array}$ & $\begin{array}{l}\text { Quanto aos fins a pesquisa é } \\
\text { descritiva e metodológica. } \\
\text { Quanto aos meios a pesquisa é } \\
\text { bibliográfica, documental e de } \\
\text { campo. } \\
\text { Para coleta de dados foi utilizado o } \\
\text { método dedutivo, através da } \\
\text { aplicação de questionário. }\end{array}$ \\
\hline \begin{tabular}{|lr} 
Intervalo & Literário \\
uma alternativa de \\
marketing & cultural \\
para o & turismo \\
goianiense &
\end{tabular} & $\begin{array}{l}\text { Se a literatura é uma fonte de } \\
\text { divulgação turística e de } \\
\text { patrimônio histórico-cultural, } \\
\text { como se vê nas obras de Cora } \\
\text { Coralina que exaltavam a } \\
\text { Cidade de Goiás e suas } \\
\text { tradições, não seria } \\
\text { recomendável se utilizar desta } \\
\text { mídia como forma de se } \\
\text { promover empresas do setor } \\
\text { turístico e desenvolver a arte li- } \\
\text { terária? assim, seria viável a } \\
\text {-Sendo as ano de um plano de } \\
\text { aplicação de um } \\
\text { marketing cultural, com ênfase } \\
\text { na arte literária em Goiânia, } \\
\text { como vem a propor este projeto? }\end{array}$ & $\begin{array}{l}\text { Em todas as áreas artísticas pode- } \\
\text { se aplicar o marketing cultural com } \\
\text { sucesso, porém a arte literária } \\
\text { possui características singulares } \\
\text { em relação às outras artes. Este } \\
\text { projeto vem a demonstrar como } \\
\text { um livro pode se tornar uma } \\
\text { grande mídia a favor das } \\
\text { empresas, em especial, do setor } \\
\text { turístico, beneficiando a integração } \\
\text { da cultura, comunidade e iniciativa } \\
\text { privada. }\end{array}$ & $\begin{array}{l}\text { Geral: } \\
\text {-Desenvolver o marketing cultural para o } \\
\text { setor turístico, em Goiânia, com ênfase na } \\
\text { arte literária. } \\
\text { Específicos: } \\
\text {-Pesquisar bibliografia relativa ao tema; } \\
\text {-Pesquisar fontes primárias, por meio de } \\
\text { questionários e entrevistas; } \\
\text {-Identificar as leis fiscais de incentivo à } \\
\text { cultura no âmbito federal (Brasil), estadual } \\
\text { (Goiás) e municipal (Goiânia); } \\
\text {-Analisar a possibilidade de parcerias para } \\
\text { a viabilidade financeira deste projeto. }\end{array}$ & $\begin{array}{l}\text { Pesquisa bibliográficas } \\
\text { documentais; } \\
\text { Pesquisa de campo com aplicação } \\
\text { de questionários. }\end{array}$ \\
\hline $\begin{array}{lrr}\text { Programa } & \text { de } \\
\text { Treinamento para a } \\
\text { Qualidade r na } \\
\text { Recepção r dos } \\
\text { Pequenos Hotéis no } \\
\text { Entorno da Rodoviária } \\
\text { de Goiânia }\end{array}$ & $\begin{array}{l}\text { Como promover a melhoria da } \\
\text { qualidade nos serviços } \\
\text { prestados na Recepção dos } \\
\text { pequenos hotéis no entorno da } \\
\text { Rodoviária de Goiânia/GO em } \\
\text { busca do encantamento do } \\
\text { cliente? }\end{array}$ & 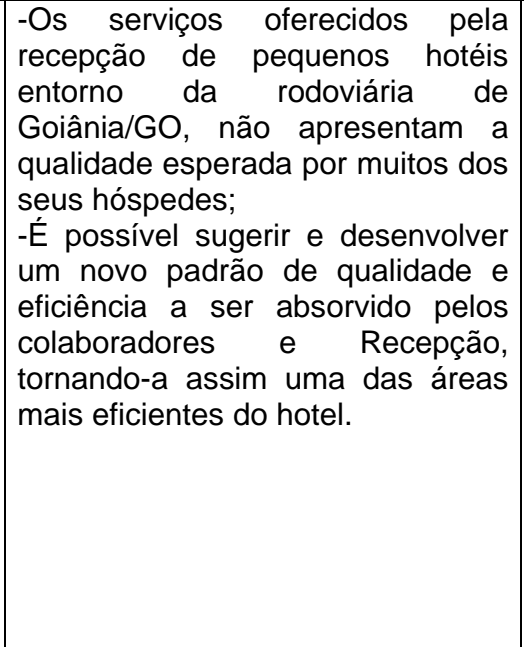 & $\begin{array}{l}\text { Geral: } \\
\text { Promover a melhoria no atendimento da } \\
\text { recepção, a partir do desenvolvimento de } \\
\text { uma proposta de programa de treinamento } \\
\text { para a qualidade, voltado para pequenos } \\
\text { hotéis no entorno da rodoviária de Goiânia. } \\
\text { Específicos: } \\
\text {-Propor uma ferramenta gerencial, visando } \\
\text { a melhoria contínua dos padrões dos } \\
\text { serviços prestados aos hóspedes; } \\
\text {-Fazer com que o cliente não se sinta um } \\
\text { problema, mas a nossa solução; } \\
\text {-Fazer com que a qualidade seja assumida } \\
\text { por todas as pessoas que fazem parte da } \\
\text { organização; } \\
\text {-Trabalhar para que a qualidade dos } \\
\text { produtos e serviços se torne percebida; } \\
\text {-Oferecer um serviço personalizado. }\end{array}$ & $\begin{array}{l}\text { A metodologia utilizada neste projeto } \\
\text { se constituirá em três etapas: } \\
\text { Pesquisa Bibliográfica, Quantitativa e } \\
\text { Qualitativa Descritiva, e Observação } \\
\text { Assistemática Participante. }\end{array}$ \\
\hline
\end{tabular}




\begin{tabular}{|c|c|c|c|c|}
\hline $\begin{array}{lrr}\text { Porto Real Transporte } \\
\text { e Turismo } & - \\
\text { implantação de } & \text { um } \\
\text { departamento } & \text { de } \\
\text { marketing } & \text { e } \\
\text { desenvolvimento } & \text { do } \\
\text { departamento } & \text { de } \\
\text { vendas } & \end{array}$ & $\begin{array}{l}\text { Como a empresa, Porto Real } \\
\text { Transporte e Turismo, poderá } \\
\text { conseguir alavancar suas } \\
\text { vendas e obter retorno lucrativo } \\
\text { que tinha alguns anos atrás? }\end{array}$ & $\begin{array}{l}\text { Um Departamento de Marketing e } \\
\text { o de Vendas fortalecidos serão os } \\
\text { responsáveis diretos pelo sucesso } \\
\text { da organização, eles alavancarão } \\
\text { as vendas, gerarão divisas e por } \\
\text { conseguinte, valorizarão a } \\
\text { empresa no mercado. }\end{array}$ & $\begin{array}{l}\text { Geral: } \\
\text { Implantar um departamento de Marketing } \\
\text { que assegure a imagem e o posicionamento } \\
\text { da Porto Real no mercado concorrente, } \\
\text { aprimorando por conseguinte o } \\
\text { departamento de vendas. } \\
\text { Específicos: } \\
\text {-Melhorar a imagem da empresa no } \\
\text { mercado; } \\
\text {-Maximizar a satisfação dos consumidores; } \\
\text { Alavancar as vendas; } \\
\text {-Tornar a empresa mais competitiva no } \\
\text { mercado concorrente. }\end{array}$ & $\begin{array}{l}\text { Pesquisa-ação e quanto aos fins } \\
\text { intervencionista. }\end{array}$ \\
\hline $\begin{array}{l}\text { Criação de um Banco } \\
\text { de Dados Turísticos } \\
\text { para o Município de } \\
\text { Trindade }\end{array}$ & 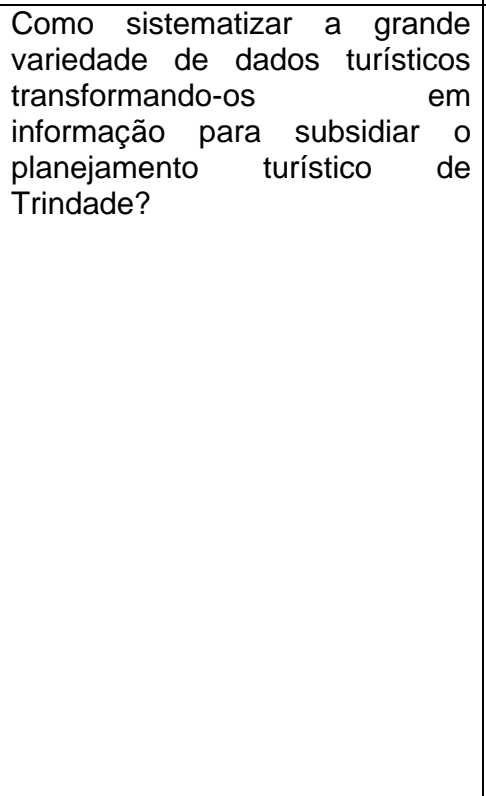 & $\begin{array}{l}\text {-Não é possível desenvolver um } \\
\text { planejamento turístico para o } \\
\text { município de Trindade sem } \\
\text { informações para sustenta-lo; } \\
\text {-O Banco de Dados é uma } \\
\text { ferramenta eficaz para } \\
\text { estruturação do projeto } \\
\text { planejamento do turismo em } \\
\text { Trindade. }\end{array}$ & $\begin{array}{l}\text { Geral: } \\
\text { Criar um banco de dados sistematizado que } \\
\text { disponibilize informações aos diferentes } \\
\text { níveis de ações da atividade turística, } \\
\text { facilitando assim a disseminação destas } \\
\text { informações sobre o município de Trindade. } \\
\text { Específicos: } \\
\text {-Promover a divulgação das ofertas } \\
\text { turísticas da região através da } \\
\text { disponibilização das mesmas aos turistas; } \\
\text {-Fornecer à administração municipal } \\
\text { subsídios que possam orienta-los no } \\
\text { planejamento de um turismo sustentável; } \\
\text {-Servir como indicador do grau de } \\
\text { preparação do local para receber visitantes, } \\
\text { através do conhecimento das possibilidades } \\
\text { turísticas do município; } \\
\text {-Servir como intercâmbio eficaz entre os } \\
\text { turistas e os atrativos turísticos do local; } \\
\text {-Contribuir para a melhoria da qualidade } \\
\text { dos serviços de informações turísticas da } \\
\text { cidade no âmbito nacional. }\end{array}$ & $\begin{array}{l}\text { A pesquisa terá } 3 \text { etapas com } \\
\text { metodologias diversificadas, } \\
\text { conforme sua função em relação ao } \\
\text { objetivo proposto pela pesquisa: } \\
\text { pesquisa bibliográfica, pesquisa } \\
\text { descritiva da oferta turística e } \\
\text { pesquisa descritiva da demanda } \\
\text { turística. }\end{array}$ \\
\hline $\begin{array}{l}\text { Casas de } \begin{array}{r}\text { Apoio a } \\
\text { serviço }\end{array} \text { médico } \\
\text { hospitalar }- \text { perfil de } \\
\text { demanda proveniente } \\
\text { de outras cidades }\end{array}$ & $\begin{array}{l}\text { A demanda de pacientes de } \\
\text { outras regiões que vem a } \\
\text { Goiânia/GO hospedando-se em } \\
\text { Casas de Apoio com a intenção } \\
\text { de receber atendimento médico } \\
\text { é significativo para o turismo na } \\
\text { cidade de Goiânia? }\end{array}$ & $\begin{array}{l}\text {-A demanda de pacientes de } \\
\text { outras regiões que vem a } \\
\text { Goiânia/GO hospedando-se em } \\
\text { Casa de Apoio com a intenção de } \\
\text { receber atendimento médico, } \\
\text { apesar de ser ampla } \\
\text { quantitativamente, não é } \\
\text { significativa no ponto de vista } \\
\text { econômico para o turismo na } \\
\text { cidade de Goiânia/GO. } \\
\text {-A demanda de pacientes de }\end{array}$ & $\begin{array}{l}\text { Geral: } \\
\text { Identificar o perfil da demanda de pacientes } \\
\text { que se deslocam a Goiânia/GO, } \\
\text { provenientes de outras cidades e se } \\
\text { hospedam em Casas de Apoio, } \\
\text { caracterizando uma modalidade de turismo } \\
\text { de saúde com caráter social. } \\
\text { Específicos': } \\
\text {-Apresentar o histórico do Turismo de } \\
\text { Saúde no Mundo; } \\
\text {-Apontar como o Turismo de Saúde é }\end{array}$ & $\begin{array}{l}\text { Quanto aos fins a pesquisa proposta } \\
\text { neste projeto será descritiva } \\
\text { quantitativa não probabilística. } \\
\text { A pesquisa se dará em etapas } \\
\text { distintas, sendo bibliográfica e de } \\
\text { campo. }\end{array}$ \\
\hline
\end{tabular}




\begin{tabular}{|c|c|c|c|c|}
\hline & & $\begin{array}{l}\text { outras regiões que vem a } \\
\text { Goiânia/GO em busca de } \\
\text { atendimento médico e se hospeda } \\
\text { em Casas de Apoio representa um } \\
\text { mercado importante a ser } \\
\text { explorado no turismo da cidade, } \\
\text { porém não é valorizada pelas } \\
\text { autoridades competentes. }\end{array}$ & $\begin{array}{l}\text { praticado atualmente; } \\
\text {-Conhecer a origem, os equipamentos } \\
\text { turísticos utilizados por estes turistas, assim } \\
\text { como o tempo que permanecem na cidade } \\
\text { de Goiânia; } \\
\text { Geral: } \\
\text { Obter dados de mercado importantes para o } \\
\text { trade turístico de Goiânia a partir da } \\
\text { identificação da demanda turística } \\
\text { proveniente do turismo de saúde em } \\
\text { Goiânia/GO e que se hospedam em Casas } \\
\text { de Apoio; } \\
\text { Específicos: } \\
\text {-Fornecer aos órgãos de planejamento do } \\
\text { Estado de Goiás um estudo sobre o } \\
\text { Turismo de Saúde em Goiânia, focando as } \\
\text { Casas de Apoio que hospedam os } \\
\text { pacientes de baixa renda; } \\
\text {-Conhecer a importância dessas Casas de } \\
\text { Apoio para a população de baixa renda; } \\
\text {--Apresentar sugestões com a finalidade de } \\
\text { melhorar o serviço prestado ao visitante que } \\
\text { chega a Goiânia/Go para atendimento } \\
\text { médico. }\end{array}$ & \\
\hline $\begin{array}{l}\text { Perfil dos eventos } \\
\text { sociais como recurso } \\
\text { ao incremento do } \\
\text { Turismo no Município } \\
\text { de Goiânia }\end{array}$ & $\begin{array}{l}\text { Goiânia tem um enorme } \\
\text { potencial turístico, porém pouco } \\
\text { explorado e incentivos } \\
\text { insuficientes. Portanto, qual o } \\
\text { perfil dos eventos sociais e o } \\
\text { seu potencial para incrementar o } \\
\text { turismo no município de } \\
\text { Goiânia/GO? }\end{array}$ & $\begin{array}{l}\text {-Os eventos sociais em Goiânia } \\
\text { não têm o apoio necessário ao seu } \\
\text { desenvolvimento e incremento, } \\
\text { desmotivando a criação de um } \\
\text { projeto significativamente } \\
\text { importante e promissor. } \\
\text {-A demanda de eventos sociais em } \\
\begin{array}{l}\text { Goiânia é abundante, porém seu } \\
\text { aproveitamento é inversamente } \\
\text { proporcional. }\end{array}\end{array}$ & $\begin{array}{l}\text { Geral: } \\
\text { Identificar o perfil dos eventos sociais } \\
\text { visando analisar o seu potencial para o } \\
\text { incremento do turismo no município de } \\
\text { Goiânia/GO. } \\
\text { Específicos: } \\
\text {-Identificar o potencial de geração de } \\
\text { empregos devido a terceirização de } \\
\text { serviços e parcerias. } \\
\text {-Conhecer o grau de envolvimento de } \\
\text { diferentes empresas que buscam evidenciar } \\
\text { sua marca. } \\
\text {-Conhecer o grau de incentivo que os } \\
\text { eventos sociais dão ao turismo de curta e } \\
\text { longa distância. } \\
\text {-Perceber o incremento na demanda em } \\
\text { hospedagens, bares e restaurantes gerado } \\
\text { pelos eventos sociais. }\end{array}$ & $\begin{array}{l}\text { A metodologia utilizada será a } \\
\text { pesquisa exploratória e descritiva. } \\
\text { A coleta de dados será o método de } \\
\text { inquérito ou contato pessoal. } \\
\text { Como instrumentos da coleta de } \\
\text { dados serão utilizados: } \\
\text {-visitas / observativas; } \\
\text {-entrevistas; } \\
\text { análises de documentos; } \\
\text { textos e documentos. }\end{array}$ \\
\hline $\begin{array}{l}\text { SPA como forma de } \\
\text { Saúde, Lazer e e } \\
\text { Entretenimento }\end{array}$ & $\begin{array}{l}\text {-Qual a possibilidade de os } \\
\text { SPAs serem trabalhados como } \\
\text { forma de lazer e entretenimento } \\
\text { no segmento turístico? }\end{array}$ & $\begin{array}{l}\text { O ponto importante do presente } \\
\text { trabalho seria mostrar que os } \\
\text { SPAs não são freqüentados } \\
\text { apenas por pessoas obesas, mas }\end{array}$ & $\begin{array}{l}\text { Geral: } \\
\text { Apresentar ao público os SPAs não } \\
\text { somente como espaço de estética, mas } \\
\text { também como espaço de lazer. }\end{array}$ & Pesquisas bibliográficas e de campo. \\
\hline
\end{tabular}




\begin{tabular}{|c|c|c|c|c|}
\hline & $\begin{array}{l}\text {-Como será o desenvolvimento } \\
\text { de um SPA como forma de } \\
\text { lazer? } \\
\text {-A estética e o lazer caminham } \\
\text { juntos? } \\
\text {-Em Goiânia, existe algum SPA } \\
\text { que trabalha a estética, o lazer e } \\
\text { a saúde concomitantemente? }\end{array}$ & $\begin{array}{l}\text { também por pessoas estressadas } \\
\text { que vão à procura de descanso, } \\
\text { sem comprometer a saúde. }\end{array}$ & $\begin{array}{l}\text { Específicos: } \\
\text {-Introduzir o SPA no segmento turístico; } \\
\text {-Disponibilizar informações de SPAs } \\
\text { relativas ao turismo, para que possam } \\
\text { atender às necessidades dos interessados } \\
\text { e até mesmo para os que não conhecem } \\
\text { este segmento; } \\
\text {-Despertar nos empresários do ramo } \\
\text { hoteleiro (SPA) o interesse em desenvolver } \\
\text { o lazer e o entretenimento em seus } \\
\text { empreendimentos; } \\
\text {-Propor aos empresários parcerias com } \\
\text { outras empresas para desenvolver o } \\
\text { crescimento no mercado. }\end{array}$ & \\
\hline $\begin{array}{l}\text { OSCIP - inclusão } \\
\text { social na hotelaria - } \\
\text { CIT - TUR }\end{array}$ & \begin{tabular}{l}
-Quais são as necessidades \\
desse mercado? \\
-Qual a solução para essas \\
pessoas? \\
-Como usar o recurso do FAT \\
(Fundo de Apoio ao \\
Trabalhador) de forma \\
adequada? \\
-Qual o tempo necessário para \\
essa formação? \\
-Qual a real necessidade do \\
mercado para estar englobando \\
essa mão-de-obra? \\
-Qual a qualificação da mão-de- \\
obra atual no mercado (cursos)? \\
-Existe disponibilidade de \\
recursos governamentais? E das \\
pessoas interessadas? \\
\multicolumn{4}{|l}{-Os cursos oferecidos na } \\
atualidade são realmente de \\
qualidade?
\end{tabular} & $\begin{array}{l}\text { Sabemos que o setor hoteleiro } \\
\text { apresenta deficiência de mão-de- } \\
\text { obra especializada, por isso, a } \\
\text { CIT-TUR atenderá a às } \\
\text { necessidades, fomentará a } \\
\text { inclusão de mão-de-obra } \\
\text { desqualificada e poderá } \\
\text { desenvolver atividades capazes de } \\
\text { resgatar sua dignidade. }\end{array}$ & $\begin{array}{l}\text { Geral: } \\
\text { Promover o investimento no capital social, } \\
\text { por meio da criação de uma "Organização } \\
\text { da Sociedade Civil de Interesse Público" } \\
\text { (OSCIP), totalmente voltada para a inclusão } \\
\text { de mão-de-obra qualificada no mercado de } \\
\text { trabalho na forma de cursos de capacitação } \\
\text { em áreas bem específicas, hotelaria. } \\
\text { Específicos: } \\
\text {-Apresentar uma nova forma de } \\
\text { investimento em cidadãos que ainda estão } \\
\text { fora do mercado de trabalho por estarem } \\
\text { desqualificados ou por não apresentarem } \\
\text { cursos específicos; } \\
\text {-buscar novas soluções para o mercado na } \\
\text { Administração de Recursos Humanos, } \\
\text { dando oportunidade de inserção desta mão- } \\
\text { de-obra; } \\
\text {-buscar parcerias e recursos com entidades } \\
\text { públicas e privadas como o FAT (Fundo } \\
\text { Apoio ao Trabalhador); } \\
\text {-capacitar os futuros ingressos no mercado } \\
\text { de trabalho, fazendo com que estejam } \\
\text { realmente preparando para tal; } \\
\text {-trazer soluções inteligentes para } \\
\text { estabelecimentos conveniados que estes } \\
\text { possam contratar mão-de-obra qualificada; } \\
\text {-investir em capital social. }\end{array}$ & $\begin{array}{l}\text { Metodologia descritiva. } \\
\text { Este projeto foi elaborado por meio } \\
\text { de pesquisas bibliográficas, técnicas } \\
\text { de estudo além de entrevistas } \\
\text { individuais. }\end{array}$ \\
\hline
\end{tabular}


"No aprender a aprender existe o encontro propício da qualidade formal e política, tornando a vida acadêmica, ao mesmo tempo, educativa e científica. Universidade tem de específico, neste contexto, educar pela ciência. Ciência que não seja somente domínio técnico, é aquela que une teoria e prática, junta qualidade formal e política, funda processos emancipatórios."

Pedro Demo.

\section{ANÁLISE DOS TRABALHOS QUANTO À PRODUÇÃO DO CONHECIMENTO}

Segundo Salvador (1986, p.10), "as funções do ensino superior podem ser resumidas no trinômio ensino-pesquisa-profissão, cujo centro ou eixo de rotação é a pesquisa, como fonte que alimenta o desenvolvimento científico-técnico, literário e artístico".

Ressalta ainda que (1986, p.13) os estudos na graduação "são recursos excelentes de integração social, não só enquanto instrumentalizam, mas, sobretudo enquanto formação pessoal, científica e profissional."

A graduação oportuniza a inserção do acadêmico na pesquisa científica, ou pesquisa enquanto princípio educativo que é uma forma de produção cultural conforme coloca Demo, muito utilizada nesse primeiro momento.

Partindo deste pressuposto, é que a análise dos trabalhos teve por critério verificar a relevância dos temas, conteúdo, pesquisa, respeitando a iniciação do acadêmico na produção do conhecimento.

$\mathrm{Na}$ construção do "Quadro de Análise dos Trabalhos", verificou-se que as hipóteses não atendiam a problematização, na maioria dos trabalhos com questões abertas e possibilitando uma série de variáveis. A metodologia proposta para a pesquisa também não atendia a problematização e os objetivos elencados no trabalho.

6.1. Tema: Intervalo Literário - uma alternativa de marketing cultural para o turismo goianiense

A proposta do trabalho é relevante tanto para a produção cultural/ literária como para o turismo. O autor justifica com maestria a contribuição que o marketing cultural pode dar na divulgação de obras literárias como incentivo à cultura e ao turismo. 
Suas indagações buscam, no transcorrer do trabalho, confirmar a produção literária como fonte de divulgação turística e do patrimônio histórico-cultural, permeando a importância da participação da iniciativa pública e privada no projeto.

No primeiro momento, a metodologia utilizada no projeto foi a pesquisa bibliográfica. Nas fontes bibliográficas procurou-se demonstrar a importância das obras literárias goianas na divulgação da cultura e do turismo do estado. Nas fontes documentais, a pesquisa amparou-se nas leis de incentivos fiscais à cultura em âmbito federal, estadual e municipal. O autor propõe as Leis de Incentivos Fiscais como um meio para as entidades privadas patrocinarem obras literárias.

No segundo momento foi realizado pesquisa de campo, com aplicação de questionários com perguntas fechadas, numa amostragem de 150 calouros da UCG (Universidade Católica de Goiás) de 2003/1, em um universo de 3.570 calouros.

O resultado, exposto abaixo, é relevante para compreensão do valor que a literatura tem no universo pesquisado.

- Na pesquisa constatou-se que: $85,3 \%$ dos calouros têm menos de 21 anos; $60 \%$ são do sexo feminino; $68,66 \%$ são oriundos da rede de ensino particular.

- 35,3\% compraram de um a três das obras literárias indicadas para o vestibular da UCG; 30,6\% fotocopiaram de uma a seis obras; e ainda, $35,33 \%$ dos alunos, afirmaram que leram de uma a três as obras mas por empréstimo.

- 40,66\% não compram os livros por terem um custo elevado.

- 50,70\% responderam nenhum, quando perguntados quantos livros goianos haviam lidos espontaneamente.

- $60,66 \%$ responderam que poderão ler outros livros da literatura goiana no futuro.

- $64 \%$ acharam as obras goianas indicadas para o vestibular boas.

- 94,7\% acharam importante a indicação das obras goianas e 83\% acharam importante por valorizar a cultura local.

- 70,7\% dos entrevistados consideram as obras literárias goianas como sendo boas ou ótimas opções de lembranças turísticas e, 50,7\% indicariam pelo menos uma obra ao turista. 
Realizou-se ainda, entrevistas com questionários com perguntas abertas, e a mostra teve como universo o diretor de uma editora goiana e uma gerente de uma livraria voltada para cultura goiana.

$\mathrm{Na}$ entrevista com o diretor da editora foi constatado que:

- Os estilos literários contos e crônicas, são os que têm maior oferta e demanda, indicando uma procura por leituras rápidas, obras com várias histórias.

- As maiores vendas da editora foram obras indicadas para o vestibular.

- O mercado literário está em crescimento no Brasil e em Goiás.

- Uma forma de incentivar e divulgar a literatura são os concursos literários. Na entrevista com a gerente da livraria verificou-se:

- Que não há muita procura pelas obras de autores goianos, a não ser as indicadas para o vestibular e, exceções como Cora Coralina, conhecida nacionalmente, Bariani Ortêncio, Augusta Faro e mais alguns.

- Alguns clientes são influenciados pela lista dos mais vendidos e pelos comentários dos críticos literários.

- Os turistas, principalmente de outros estados, procuram por obras goianas, e Cora coralina é sempre a primeira a ser lembrada, mas pedem sugestões quanto a outros autores.

- A gerente considera que uma obra literária de autores do estado, o qual está sendo visitado, é uma lembrança turística.

- A livraria oferece um espaço reservado só para obras goianas, onde tem um quadro de Cora Coralina que chama atenção, e isto seria, no caso, uma estratégia de vendas.

A proposta do autor é verificar a viabilidade da aplicação de um plano de marketing cultural com ênfase na arte literária em Goiânia, para divulgação turística e do patrimônio histórico-cultural. Para viabilizar a proposta, o autor coloca como objetivos a possibilidade de parcerias financeira do projeto e a utilização das leis de incentivos fiscais para a cultura.

O autor desenvolve uma relevante pesquisa bibliográfica pertinente ao tema proposto, porém, na aplicação da pesquisa de campo, o universo escolhido para aplicação dos questionários, não corresponde ao universo de pessoas que responderiam aos questionamentos, e nem aos objetivos propostos. 
O possível público consumidor de obras literárias goianas que poderiam ser motivados a comprarem as obras descritas no projeto, seriam turistas e mesmo pessoas de outros lugares. O que é uma incoerência do universo pesquisado, que se restringiu somente aos estudantes que fizeram a prova do vestibular em janeiro de 2003, na UCG e que de qualquer forma eram 'obrigados' a ler as obras indicadas. Pode-se considerar, portanto, que a pesquisa realizada não responde aos questionamentos elencados e as afirmações que o autor faz a partir da pesquisa, sabendo-se que, "os resultados da pesquisa dependem da quantidade e, sobretudo, da qualidade dos dados coletados." (Salvador, 1986, p.73)

O autor fala de parceria, mas não insere a academia como um espaço relevante na contribuição do 'marketing cultural", volta-se apenas para o trade turístico (iniciativa privada) e os órgãos públicos como Secretaria da Cultura, Secretaria de Turismo (iniciativa pública). Os calouros foram o universo de pesquisa, e no entanto, deveriam ajudar ou mesmo realizarem a pesquisa, pois, supostamente leram alguns livros da literatura goiana e entenderiam melhor a pesquisa.

O autor conclui (ver conclusão anexo), com várias afirmações, a principal delas é que o projeto é viável, porém, nas pesquisas realizadas, bibliográfica e de campo, não fornece subsídios suficientes para confirmar suas hipóteses.

A fala da gerente da livraria é muito clara quando informa que a procura por livros literários de autores goianos é pequena. Neste caso, o autor perdeu, uma grande oportunidade de trabalhar com a interdisciplinaridade intrínseca do turismo, buscando viabilizar seu projeto em parceria com colegas de outros cursos.

Segundo Ansarah (2002, p.39), faz-se necessário o esforço na realização de pesquisa aplicada porque:

\begin{abstract}
A pesquisa aplicada em turismo visando ao desenvolvimento de novos conteúdos tem sido relegada a segundo plano, comprometendo a evolução do setor. É fundamental a formatação de um programa educativo que agregue instituições de ensino, empresa e demais segmentos envolvidos focando a inovação e o desenvolvimento do setor face da realidade local. A aplicação prática e o desenvolvimento do setor em face da realidade local. A aplicação prática dos conteúdos e sua conseqüente evolução em termos conceituais é ferramenta estratégica fundamental para o aprimoramento do setor turístico.
\end{abstract}

Finalizando, não houve argumentação justificando a relevância do tema, a contribuição para construção do saber turístico. 
6.2. Tema: Inclusão social na Hotelaria: CIT-TUR.

A escolha do tema dá início ao processo de planejamento e define a área de interesse que será pesquisada. O tema deve ser do interesse do pesquisador e estar situado em sua área de conhecimento.

Para Barros e Lehfeld in Dencker (2000, p.61), "a proposta de estudo deve ser avaliada em termos de sua viabilidade. Viabilidade técnica, política, lógica e financeira."

A delimitação do tema tem como proposta a: criação de uma OSCIP (Organização da Sociedade Civil de Interesse Público), buscando iniciativas inovadoras de desenvolvimento social, no seguimento (sic), da hotelaria.

A argumentação utilizada no projeto, quanto a sua viabilidade, é que o mercado sofre com a deficiência de mão-de-obra qualificada sem a devida capacitação e atualização em áreas específicas.

Os vários problemas e objetivos elencados no projeto pressupõem uma pesquisa que atenda essas indagações.

Segundo Dencker (2000, p.61), "para desenvolver de maneira adequada um tema de pesquisa, é necessário que o pesquisador domine o assunto e esteja apto a manejar as fontes de consulta bibliográfica."

Nesse processo, é imprescindível o papel do orientador que fará referências à teorias pertinentes ao tema, bem como ajudará na delimitação e na metodologia do projeto.

Analisando o trabalho, percebe-se que os acadêmicos não atentaram para a metodologia científica adequada ao desenvolvimento do projeto. O trabalho está confuso, na justificativa do tema, entendido como (Dencker, 2000, p.62): "exposição dos motivos pelos quais se optou pela investigação, o motivo que levou a definição do tema escolhido e qual a finalidade da investigação. Foi feita uma revisão da literatura abordando a importância social e econômica do turismo no mundo e no Brasil, da indústria "hoteleira, no Brasil e seus reflexos sociais e econômicos.

É na seção "Marcos teóricos" do projeto que se analisa a situação atual do conhecimento mediante a revisão da literatura existente, buscando-se pesquisas similares sobre o tema, conceitos, explicações e modelos teóricos existentes com o objetivo de situar o estudo no contexto geral do conhecimento. (DENCKER, 2000, p.68). 
Tanto no marco teórico, como na justificativa, são feitas citações de alguns autores - ressaltando que não foram citados nas referências bibliográficas - que discorrem sobre a importância sócio-econômica do turismo e hotelaria. Em seqüência, uma abordagem com conceitos sobre ONG (Organização NãoGovernamental), o terceiro setor e a responsabilidade social.

Os acadêmicos restringem-se apenas a textos compilados de livros e internet, não justificando a metodologia proposta. No item subseqüente argumentam sobre o projeto que se propõem a promover. Expõem uma série de itens que irão oferecer quando a CIT-TUR estiver implementada. São ações propostas sem embasamentos que justifiquem a viabilidade do projeto.

A falta de "lógica" ou entendimento do trabalho é explicita, pois a seqüência apresentada na revisão da literatura é: o histórico da hotelaria, a hotelaria no mundo e no Brasil, a estrutura do hotel física, pessoal e econômica, e o RH.

Nas considerações finais, os acadêmicos concluem uma série de necessidades (vide anexo), sem, no entanto, realizarem pesquisas que fundamentem essas conclusões.

A Professora Mirian Rejowski ${ }^{2}$ coloca a importância das monografias como forma de aquisição de conhecimento e informação, apesar de o ensino superior brasileiro, na área de turismo, indicar tênue preocupação para com a pesquisa na graduação.

Diante desse fato, é primordial a confiabilidade e embasamento de conclusões e proposições elencadas nas monografias defendidas e/ou apresentadas na graduação. É um momento ímpar de contribuição e discussão na produção do conhecimento do turismo, e neste contexto o professor-orientador é peça fundamental.

No artigo, o Papel do Orientador de Leandro Rodrigues ${ }^{3}$, com vários entrevistados, discute-se que:

- ao acompanhar a realização de trabalhos de conclusão de curso, os professores se colocam na posição delicada de apontar caminhos e orientar a linha de pensamento;

\footnotetext{
${ }^{2}$ REJOWSKI, Mirian. Turismo e Pesquisa Científica. 5ed. Campinas-SP: Papirus, 1996. Coleção Turismo 
- o orientador não é dono do trabalho. Ele contribui com sua experiência, mostrando as possibilidades de cada idéia, algo como na minha opinião é assim, mas se vocês quiserem seguir em frente, tudo bem, diz Francisco de Paula, coordenador de Projetos Experimentais do Curso de Publicidade da Universidade Potiguar (UNP).

\subsection{Tema: A Dinâmica das Visitas Técnicas das IES de Goiânia.}

O trabalho desenvolvido é explicitamente científico e perpassa pela vontade do pesquisador de comprovar a visita técnica como uma ferramenta de produção cientifica nas IES. O embasamento teórico, apesar da limitação, imposto pelo próprio tema, dimensiona a importância do mesmo na produção de conhecimento.

O autor da monografia justifica a importância de que, através de sua pesquisa, as IES terão subsídios para que possam por meio de análise dos resultados obtidos inserir, programar e ou melhorar a dinâmica das visitas realizadas pelos seus alunos.

Tem como objetivo identificar, nas IES de Goiânia, a dinâmica de realização dessas visitas, no período de 1998 até 2001. Questiona se as IES têm um processo estruturado e similar para organização e o desenvolvimento das visitas técnicas.

Nas suas hipóteses, é possível perceber que é a partir de sua vivência acadêmica, produção literária (o Livro Visita Técnica - uma investigação acadêmica, de sua autoria), observação pessoal e pesquisa informal que afirma:

- a participação do aluno na prática (organização e escolha do local) da visita técnica é parcial, tanto em relação ao quantitativo existente em sala, quanto ao exercício em campo;

- a visita técnica, pelo seu caráter e envolvimento teórico e prático que resulta em produção de técnicas e atividades de cunho profissionalizante, diferencia-se, assim, da conceituação de turismo cultural, científico, de estudos ou educacional;

- as IES não têm um processo estruturado e similar para organização e desenvolvimento das visitas técnicas.

Na sua pesquisa teórica reflete o esforço de construir um "marco teórico" para o tema e, ao mesmo tempo, perpassa pela vontade de referendar suas próprias convicções, ou por assim dizer, de "conceituar" visita técnica. 
Sobrepujando essa vontade, o autor se ampara na importância do que vem a ser pesquisa e suas variáveis, apreendendo que a visita técnica e a pesquisa de campo têm suas particularidades e similaridades que se complementam e até se conjugam.

A colocação de "Visita técnica", como pesquisa de campo, poderia ser traduzida como investigação científica, se levar em consideração o que sugere Dencker (1998, p. p.23) "Três elementos formam a base da investigação científica e caracterizam o conhecimento como ciência: a teoria, o método e a técnica."

A citação reforça a preocupação de cientificidade do autor e, conseqüentemente, a sua vontade de promover teoria e prática, envolvendo a IES, docentes e discentes no planejamento e execução da visita, e ao fazê-lo estará produzindo conhecimento.

Outra proposta do autor é a interdisciplinaridade que a visita técnica propicia, agregando saberes diversos e oportunizando ao acadêmico uma visão múltipla das diversas disciplinas do curso.

Em sua conclusão (vide anexo), o autor explana sobre os resultados de sua pesquisa: o projeto de pesquisa aplicada sobre a atividade denominada visita técnica norteado pelos conhecimentos, embasamentos teóricos e pela própria convivência com esse tema durante todo o curso, facilita opinar, sugerir e diagnosticar como esse instrumento está sendo considerado pelas IES de Goiânia, como elemento científico de pesquisa da prática do fazer turismo.

Como já foi colocado anteriormente, o autor só confirmou suas suposições, embasou seus conhecimentos e reafirmou seus pressupostos.

Em conversa informal com o autor, este afirma que suas pesquisas continuam no sentido de tornar a "Visita Técnica" nos cursos de turismo, uma disciplina constante na grade curricular . 
Longe de acreditar que não há nada em que acreditar, ele acreditava que é preciso acreditar mais do que se imagina inicialmente.

Claude Roy

\section{CONSIDERAÇÕES FINAIS}

É inconcebível que diante dessa situação, não se tenha ainda, uma revista voltada para trabalhos acadêmicos, TCCs com publicações pela sua produção de conhecimento ou mesmo uma divulgação de tantos trabalhos produzidos semestralmente. O que ficou explícito na realização da pesquisa nos TCCs, foi a falta de cientificidade dos trabalhos e o descaso com a produção de conhecimento.

Numa conversa informal com alguns orientadores dos trabalhos analisados, percebeu-se que:

- o pouco tempo para realização do trabalho e um número elevado de orientandos, não permitiu um acompanhamento mais criterioso;

- a orientação foi limitada ao interesse do aluno e não pela relevância do tema, do valor dos trabalhos acadêmicos para cientificidade do turismo, pois, na maioria das vezes, o desinteresse do acadêmico não permitiu um direcionamento do orientador;

- A falta de tempo do orientador e orientando para dedicarem-se às pesquisas compromete, na maioria dos cursos, a qualidade dos trabalhos de conclusão;

- A formação do orientador não interfere no desenvolvimento do trabalho, já que este busca no corpo docente apoio para os temas específicos do curso.

Poderia haver uma continuidade e posicionamento, expondo uma série de situações, percebidas no transcorrer da pesquisa, que comprometem ou desestimulam a produção de conhecimento nos cursos de graduação, mas a preocupação principal foi dar ênfase à adequação do tema aos objetivos propostos nos trabalhos para a produção de conhecimento do turismo.

Nos três trabalhos escolhidos e analisados criteriosamente, ficou claro a vontade dos autores de inovarem, proporem um tema relevante e novo no turismo. Entretanto, fica claro, também, que as propostas, exceto o trabalho Visita Técnica, são totalmente voltadas para o mercado, não havendo a preocupação com a 
cientificidade devida a um trabalho acadêmico. Não se está exigindo trabalhos grandiosos, apenas que correspondam à iniciação científica que deve caracterizar a graduação.

O trabalho Visita Técnica surpreende por propor justamente trabalhar as visitas técnicas com um rigor científico que produza conhecimentos e não se limite a tours ou intervalos de lazer aos acadêmicos.

A convivência IES, orientador e orientando precisa acontecer, quebrando-se os paradigmas que o nosso aluno de graduação não sabe escrever nem pesquisar e que os professores não sabem orientar.

Com isso, deve-se levar em conta, que o aprendizado científico requer um rigor maior em leituras direcionadas e orientadas no sentido de que a produção de textos possa ganhar maior dimensão nos cursos de graduação. Caso contrário, a pesquisa não atingirá seu objetivo final, a produção de um conhecimento que se possa chamar de científico. 
REFERÊNCIAS BIBLIOGRÁFICAS

ANSARAH, Marília Gomes dos Reis. Formação e capacitação do profissional em turismos e hotelaria: reflexões e cadastro das instituições educacionais no Brasil. São Paulo: Aleph, 2002.

BISSOLI, Maria Ângela Marques Ambrizi. Estágio em turismo e hotelaria. São Paulo: Aleph, 2002.

CENTENO, Rogelio Rocha. Metodologia da pesquisa aplicada ao turismo: casos práticos: São Paulo, 2003.

DEMO, Pedro. Desafios modernos de educação. Petrópolis: Vozes, 1993.

.Educação e qualidade. 5 ed. Campinas, SP: Papirus, 2000.

DENCKER, Ada de Freitas Maneti. Métodos e Técnicas de Pesquisa em Turismo. 3 ed. São Paulo: Futura, 1988.

. Pesquisa e interdisciplinaridade no Ensino Superior : uma experiência no curso de turismo. São Paulo: Aleph, 2002.

DESCARTES, R. Discurso do Método. São Paulo: Abril, 1974. Col. Os Pensadores.

DOTTI, Corina Michelon. Educação: reflexões, vivências e pesquisa. Caxias do Sul: Educs, 2002.

ECO, Umberto. Como se faz uma tese. 15 ed. São Paulo: Perspectiva, 2000.

FRIGOTTO, Gaudêncio, CIAVATTA, Maria (orgs.). Teoria e educação no labirinto do capital. 2 ed. Petrópolis: Vozes, 2001.

KOURGANOFF, Wladimir. A face oculta da universidade. São Paulo: UNESP, 1990.

KOYRÉ, A. Do mundo fechado ao universo infinito, Rio de Janeiro: Forense, 1979. . Considerações sobre Descartes. Lisboa: Presença, 1986.

LOCKE, J. Ensaio acerca do entendimento humano. São Paulo: Abril, 1974. Col. Os Pensadores.

LEOPOLDO E SILVA, F. Descartes - a metafísica da modernidade. São Paulo: Moderna, 1993.

LIBÂNEO, José Carlos; OLIVEIRA, João Ferreira de; TOSCHI, Mirza Seabra. Educação escolar: políticas, estrutura e organização. São Paulo: Cortez, 2003. 
MATIAS, Marlene. Turismo: formação e profissionalização - 30 anos de história. Barueri: Manole, 2002.

MEIRIEU, Philippe. Aprender...sim, mas como? 7 ed. Porto Alegre: ARTMED, 1998.

MICHAUD, Y. Locke. Rio de Janeiro: Jorge Zahar, 1991.

MOESCH, Marutschka. A produção do saber turístico. São Paulo: Contexto, 2000.

MOLINA, Sergio. O pós-turismo. São Paulo: Aleph, 2003.

MORIN, Edgard. Ciência com consciência. 2 ed. Rio de Janeiro: Bertrand Brasil, 1998.

NETTO, Alexandre Panosso, TRIGO, Luiz Gonzaga Godoi. Reflexões sobre um novo turismo: política, ciência e sociedade. São Paulo: Aleph, 2003.

SEVERINO, Antônio Joaquim. Metodologia do trabalho científico. 21 ed. São Paulo: Cortez, 2000.

SHIGUNOV NETO, Alexandre e MACIEL, Lizete S.B. (orgs.). Currículo e formação profissional nos cursos de turismo. Campinas: Papirus, 2002.

\section{MONOGRAFIAS:}

FACULDADE CAMBURY - formandos de junho e dezembro/2002 e junho/2003.

UCG - UNIVERSIDADE CATÓLICA - formandos de junho e dezembro/2002 e junho/2003.

Sites:

http://www.mec.gov.br

Revista:

RODRIGUES, Leandro. Revista Ensino Superior. O Papel do Orientador. São Paulo, 02/2003. p.14 
ANEXOS 
ANEXO 1 - Visita técnica

\section{CONCLUSÃO}

O projeto de pesquisa aplicada sobre a atividade denominada visita técnica, norteado pêlos conhecimentos, embasamentos teóricos e pela própria convivência com esse tema durante todo o curso, facilita opinar, sugerir e diagnosticar como esse instrumento está sendo considerado pelas IES de Goiânia, como elemento cientifico de pesquisa da prática do fazer turismo.

A participação em eventos que discutem e produzem resultados necessários e importantes para se dimensionar essa atividade no contexto curricular dos cursos de turismo, inclusive as indicações de sua aplicabilidade através das diretrizes curriculares ou não inseridas pelo Ministério da Educação, fomenta o interesse dos discentes na condução, planejamento e execução, com apoio, contribuição e ordenamento de professores e instituições.

Finalmente, sob a ótica profissional ou acadêmica, o trabalho em busca de informações, citações e questionamentos, considerando a exígua bibliografia sobre o assunto, mostra que não se pode, em hipótese alguma, deixar de tratar e considerar, de suma importância para a academia, as respostas de profissionais, professores, coordenadores, enfim de todos aqueles que envolvam com a área de turismo e hotelaria, seja na aplicação da docência, seja na convivência disciplinar ou laboratorial da produção turística. As questões levantadas e apresentadas às IES de Goiânia, conjugadas com àquelas colhidas junto aos participantes do Seminário de Professores, durante o Congresso Brasileiro de Turismo, e ainda, na participação ativa dos discentes pesquisadores no mesmo evento, demonstra que a 
finalidade da pesquisa foi atingida, resultando em algumas considerações e sugestões, já previstas anteriormente, inclusive por um dos discentes pesquisadores, ainda na preparação acadêmica, quando defendia que a visita técnica deveria ser mais bem trabalhada, respeitada e utilizada pelas IES para o crescimento da consciência científica do turismo, tendo resultado na editoração do livro Visita Técnica - uma investigação acadêmica, que aqui não se questiona ou se julga, mas se propõe a sua aceitação como prova de que a pesquisa não tem tempo, ela pode e deve ser feita durante todo o tempo.

Registra-se, portanto, como base conclusiva do projeto, norteando o seu resultado às IES de Goiânia, para a ação de aconselhamento do discente e capacitação do docente, num vasto entendimento que a visita técnica não tem mais como deixar de fazer parte da vida acadêmica dos cursos de turismo e hotelaria:

- A visita técnica não tem uma dinâmica definida pelas $1 \mathrm{ES}$, nem tampouco compartilhada de similaridades;

- Percebeu-se não existir a construção de banco de dados, mas com indicativos de que esta situação é uma das maiores preocupações das IES;

- O controle e arquivo com dados estatísticos, também não oferecem segurança de informações. Não se percebeu que este serviço é um referencial utilizado pelas IES;

- O cronograma e calendário de visitas praticamente não existem, como se confirma nas participações aleatórias de turmas às visitas técnicas;

- Um ponto importante se refere à escolha das localidades, ainda existe a preocupação com o conhecer e trabalhar as cidades do estado de Goiás; 
- Sobre os atrativos, não se verificou muita utilidade entre o conhecimento prático e o teórico, já que a maioria não busca e trabalha a organização antes e depois;

- O planejamento da VT ainda não está bem compilado pelas IES. As variáveis estão confusas entre a distribuição das ações como visita técnica e pesquisa de campo (as comparações ainda são fortes);

- Considerando que as IES que responderam a pesquisa, o ano de 1998 não foi citado nos resultados. Mas a proposta teve o êxito pêlos dados referentes ao período de 1999 a 2001;

- As comparações entre os dados e informações apresentados pelas IES, pêlos profissionais e professores no Congresso Brasileiro de Turismo 2002 e da participação dos discentes pesquisadores no mesmo evento, permitiram traçar comparativos interessantes, onde se estabelece a necessidade de: planejar, organizar, discutir, melhorar o controle e criar um banco de dados que permita, ano a ano, estabelecer novas referências de visitas técnicas à luz das outras realizadas;

- A apresentação de questionário utilizado pela Faculdade Anhanguera demonstra uma preocupação daquela IES com a dimensão da produção teórica e prática da visita técnica;

- Nos outros cursos existentes nas 1ES, a maioria não realizada visita técnica. Complementado as respostas, necessário inserir alguns dados e informações apresentados pelas IES quando do questionário aplicado:

a. Faculdade Alfa:

- Os patrocínios existem para bebidas, comidas e camisetas;

- Os métodos de avaliação são seminários e relatórios; 
- Para os $3^{\circ}$ períodos em diante, as visitas são diferenciadas - realizadas através do interesse de cada turma e com base no conteúdo programático das disciplinas oferecidas no semestre, já que as visitas dos $1^{\circ}$ e $2^{\circ}$ períodos tem um caráter mais exploratório;

b. Faculdade Anhanguera

- A IES participa no custeio da visita técnica;

- Depois da elaboração dos roteiros, os atrativos são identificados relacionando-os à teoria dada em sala de aula;

- As turmas têm a liberdade de buscarem patrocínios para a confecção de camisetas, bonés, brindes para sorteios, filmes fotográficos, outros;

- A avaliação da visita técnica é feita por meio de relatório, onde contém um item sobre o aproveitamento, desempenho, aprendizado, percepção do aluno,

- Os alunos respondem um questionário onde constam todos os seus dados (confidencial) para casos de emergência;

- Somente é permitida que cada turma leve apenas uma filmadora e uma máquina fotográfica. Toda cobertura da viagem fica arquivada na Coordenação do curso;

c. Faculdade Padrão

- A avaliação é feita pêlos relatórios apresentados;

- Deve ser divulgada junto ao trade a importância da visita técnica

d. Universidade Católica de Goiás

- Houve mudança de coordenação e até o momento (da pesquisa) não ocorreu sistematicamente registro das visitas;

e. Universidade Paulista

- Classifica-se a visita técnica tendo por base os aspectos relacionados à geografia, planejamento, lazer e atividades interdisciplinares; 
- A IES custeia 50\% das despesas de transporte:

- As avaliações ensino/aprendizagem são realizadas pêlos seminários e trabalhos elaborados;

Sugestões para a consecução de visitas técnicas em todos os cursos de turismo e hotelaria, com base nos resultados da pesquisa aplicada:

- Disciplinar as visitas técnicas criando um padrão mínimo de planejamento e organização;

- Constar nas diretrizes do MEC como atividade obrigatória, instituindo a sua aplicação em grade, durante todo o curso, respeitando, conforme base da instituição, o último ano para outras atividades, tais como estágio e trabalho de conclusão de curso;

- Propor a dinamicidade e maior abertura para a literatura sobre o assunto;

- Utilizar mecanismos de planejamento e organização, tendo como referencial literatura inerente à pesquisa e visita técnica, criando a obrigatoriedade de constar no banco de pesquisa, biblioteca e nas ementas das disciplinas que contribuam ou promovam a realização da visita técnica.

- Criar um sistema de informação com banco de dados (escrito, audiovisual, gráfico);

- Transformar ou conduzir os procedimentos pós visita técnica em eventos de interesse não só da turma mas de todo o curso.

- Criar colegiado para definição, deliberação e demonstração às Instituições sobre a pertinência da instituição da visita técnica no currículo do curso de turismo e hotelaria;

- Promover normativa para a atividade denominada visita técnica. 
ANEXO 2 - Intervalo literário

\section{CONCLUSÃO}

Verificou-se que o marketing cultural não é apenas, apoiar ou patrocinar uma atividade cultural, mas refere-se a todo o processo, desde a análise da obra artística a se integrar a este plano de marketing, até ao retorno que os clientes trarão à empresa que utilizar desta estratégia e ao artista.

O movimento artístico em geral, contribui culturalmente, com o registro histórico tornando-se um patrimônio de determinadas sociedades, atraindo não só a atenção da população local, mas principalmente dos turistas que aos seus olhares (como os de crianças) tudo é novidade. E como toda novidade, qualquer ser humano, sente uma necessidade de demonstrá-la ou informá-la aos seus próximos. Os turistas ge-ralmente transmitem-na por meio de filmagens, fotografias ou cartões-postais. Tam-bém, há aqueles que gostam de presentear os seus amigos e familiares com lembranças produzidas pela região visitada.

Após ter analisado os estudos feitos por fontes secundárias pôde-se perceber que não só é viável a aplicação de um plano de marketing cultural com ênfase na literatura para o turismo goianiense, mas como há esta necessidade tanto por parte dos artistas, quanto por parte das empresas de pequeno porte que desejam se utilizar dessa estratégia, porém não se enquadram nas leis de incentivo, ou não têm condições de manterem fundações ou instituições culturais.

E com o término das análises das fontes primárias (pesquisa feita com 150 calouros, 2003/1, da UCG e entrevistas feitas com o Diretor/Presidente da Editora Kelps e com a gerente da Livraria Cultura Goiana do Araguaia Shopping/Rodoviária de Goiânia) pôde-se confirmar a viabilidade deste projeto:

seja ela financeira, pois pode-se ter os custos divididos com a editora em 50\% e/ou vendê-los a preço inferior ao de mercado, quanto de marketing já que terão divulgadas informações sobre a empresa dentro da obra, em busca de potenciais clientes.

Sendo assim, este projeto além de ser uma opção de lembrança artística também torna-se um meio de informação e divulgação, tanto do local visitado, quanto das empresas do setor turístico da região. E neste caso, divulga-se não só a marca da empresa, mas também informações sobre os seus produtos e serviços entre as páginas do livro. Podendo ser emprestado ou presenteado pêlos turistas a terceiros, aumentando a quantidade de clientes em potenciais, com cupons promocionais, ou não. Seja ele destinado ao, público infantil, jovem ou adulto. Com temas religiosos, educativos, folclóricos ou datas comemorativas. Em quadrinhos, prosa ou em roteiros teatrais, de autores novatos ou experientes. Escolhidos de forma direta, por meio das leis de incentivos fiscais ou por meio de concursos que envolvam a comunidade.

Trata-se de um intervalo no enredo durante a leitura e um intervalo durante a estada ou viagem, com o lazer literário. Principalmente, quando se pratica o turismo de negócios que não tem o lazer como principal motivação, mas que pode ser praticado. 
ANEXO 3 - Inclusão social na hotelaria - CIT-TUR

\section{9 - CONSIDERAÇÕES FINAIS}

Sabemos que o setor hoteleiro apresenta deficiência de mão-de-obra especializada, por isso, a CIT-TUR atenderá às necessidades, fomentará a inclusão de mão-de-obra desqualificada e poderá desenvolver atividades capazes de resgatar sua dignidade.

Concluímos que é real a necessidade de se criar uma escola de capacitação de pessoas, que se possa desenvolver o capital humano e trazer novamente a excelência para o nosso meio, tomando, assim, a qualidade como forma de auxílio na inclusão de mão-de-obra.

Nota-se que a realidade atual do mercado exige mais do que é ensinado. Portanto, apresentamos uma solução viável pela criação do CIT-TUR (Centro Integrado de Treinamento em Turismo) para promover investimento em capital social. 